\title{
Government Spending Shocks, Sovereign Risk and the Exchange Rate Regime
}

\author{
Dennis Bonam' \\ Jasper Lukkezen²
}

1 Faculty of Economics and Business Administration, University of Amsterdam, and Tinbergen Institute, The Netherlands;

2 Utrecht University, Utrecht, and CPB Netherlands Bureau for Economic Policy Analysis, The Netherlands. 
Tinbergen Institute is the graduate school and research institute in economics of Erasmus University Rotterdam, the University of Amsterdam and VU University Amsterdam.

More TI discussion papers can be downloaded at http://www.tinbergen.nl

Tinbergen Institute has two locations:

Tinbergen Institute Amsterdam

Gustav Mahlerplein 117

1082 MS Amsterdam

The Netherlands

Tel.: +31(0)205251600

Tinbergen Institute Rotterdam

Burg. Oudlaan 50

3062 PA Rotterdam

The Netherlands

Tel.: +31(0)10 4088900

Fax: $+31(0) 104089031$

Duisenberg school of finance is a collaboration of the Dutch financial sector and universities, with the ambition to support innovative research and offer top quality academic education in core areas of finance.

DSF research papers can be downloaded at: http://www.dsf.nl/

Duisenberg school of finance

Gustav Mahlerplein 117

1082 MS Amsterdam

The Netherlands

Tel.: +31(0)20 5258579 


\title{
Government spending shocks, sovereign risk and the exchange rate regime*
}

\author{
Dennis Bonam ${ }^{\S}$ \\ Jasper Lukkezen
}

19th December 2013

\begin{abstract}
Conventional wisdom teaches that the output response upon a fiscal expansion is higher under fixed than floating exchange rates for a small open economy. We analyse the effects of fiscal expansions using a New Keynesian model and find that this result reverses in times of sovereign default risk. Under a float, a fiscal expansion is followed by an exchange rate depreciation, which stimulates exports; under a peg, only the adverse effects of sovereign risk on private credit conditions and consumption remain. When these adverse effects are large, we show that a transient fiscal contraction may bring about positive output responses, yet only in the short run.
\end{abstract}

JEL Classification: E32, E52, E62

Keywords: Fiscal policy, government spending, exchange rate regime, sovereign risk, New Keynesian model, expansionary fiscal consolidation

*The authors would like to thank Eric Bartelsman, Luc Eyraud, Shafik Hebous, Bart Hobijn, Patrick Hürtgen, Clemens Kool and participants at the CPB, UU and TI seminars, the 2013 Euroframe conference and the ZEW summer workshop for helpful comments. All errors are ours.

${ }^{\S}$ Corresponding author. VU University Amsterdam, Email: d.a.r.bonam@vu.nl.

`Utrecht University and CPB Netherlands Bureau for Economic Policy Analysis, E-mail: j.h.j.lukkezen@cpb.nl. 


\section{Introduction}

Recently, fiscal policy has made a comeback as a viable tool for macroeconomic stabilisation, particularly in countries whose monetary policy instruments are constrained due to, for example, the zero lower bound or fixed exchange rate arrangements. Some recent studies have shown that, in order to gauge the efficacy of fiscal policy, one must take into account the exchange rate regime in place and the state of public finances (Ilzetzki et al., 2012, Corsetti et al., 2012, and Auerbach and Gorodnichenko, 2012). In contrast to conventional wisdom, we show that, in the presence of sovereign risk, fiscal multipliers are larger under flexible than fixed exchange rate regimes.

In the absence of sovereign risk, the traditional Mundell-Fleming model predicts that government spending multipliers are larger under fixed exchange rates than under floating arrangements. Specifically, a government spending shock increases aggregate demand, which drives up the real interest rate. Under a floating exchange rate regime, the nominal exchange rate then appreciates which depresses exports. Under an exchange rate peg, the central bank prevents changes in the exchange rate, which allows for a larger fiscal multiplier. These results have recently been confirmed by basic New Keynesian models featuring forward-looking households (see e.g. Galí and Monacelli, 2008, and Corsetti et al., 2011).

These models, however, are founded on the assumption that public finances are sound and that the government is solvent in the long run. To assess the implications of weak public finances, we augment an otherwise basic New Keynesian model for a small open economy by introducing non-neutral government debt. We assume government debt to be non-neutral in two ways. First, the government is able to default on its outstanding liabilities. Based on the default mechanism suggested by Schabert and van Wijnbergen (2011), uncertainty about full repayment of public debt enters the model through an exogenous "fiscal limit". When total outstanding debt exceeds this fiscal limit, a sovereign is no longer willing to pay and default ensues. Although the fiscal limit is unknown ex ante, it has a known distribution upon which default beliefs are based and investment decisions made. Second, the model allows for sovereign risk to spill over to private credit conditions. As in Corsetti et al. (2013), such asset market imperfections reflect heightened funding strains in the private sector induced by fiscal stress. We model this "sovereign risk channel" as a risk premium on private external debt which is monotonically increasing in the loss from sovereign default incurred by foreign holders of government bonds. ${ }^{1}$

The inclusion of sovereign risk alters the traditional Keynesian fiscal transmission mechanism in the following ways. When public debt is in the vicinity of the fiscal limit, a government spending shock raises default expectations. Consequently, foreign investors reduce their holdings of government bonds, triggering a depreciation of the nominal exchange rate. The exchange rate depreciation, in turn, raises exports and supports output. Furthermore, the rise in sovereign risk tightens private borrowing conditions, which crowds out household consumption. The net effect of the government spending shock on output is positive under a floating exchange rate regime, in particular when foreign demand for domestic goods is

\footnotetext{
${ }^{1}$ See Bruyckere et al. (2012) for an overview of empirical studies on the sovereign risk channel.
} 
highly elastic and the economy is more open to trade. Under a fixed exchange rate regime, the central bank does not allow the nominal exchange rate to depreciate and only the crowding-out effects of fiscal policy remain. The net effect on output then depends on the strength of the sovereign risk channel and can even be negative. Thus, in the presence of sovereign risk, we obtain larger output responses under flexible exchange rates than under fixed exchange rates, which contrasts the Mundell-Fleming conclusions. This is the main result of the paper.

We test these results empirically following the two-step methodology suggested by Corsetti et al. (2012). In the first step, we regress a simple fiscal rule and proxy exogenous changes in fiscal policy by the residuals obtained from these regressions. In the second step, we estimate the effects of government spending shocks by using the residuals as explanatory variables. For a number of OECD countries, we find that the effects of government spending shocks on output are larger under fixed exchange rates in the absence of sovereign risk. When conditioning on weak public finances, however, we find that the reverse holds: the effects of government spending on output are larger under flexible than under fixed exchange rates. In line with our theoretical predictions, these results seem to be driven by the exchange rate, which appreciates without sovereign risk, yet depreciates in the presence of sovereign risk.

Our results suggest the possibility of so called non-Keynesian effects of fiscal policy. We find that a transient reduction in government spending can bring about a positive output response. Particularly, an improvement in the fiscal balance allows for a reduction in the risk premium on household loans and hence an increase in private consumption. The stronger is the sovereign risk channel, the more likely it is that the fiscal consolidation will be expansionary. Furthermore, the fall in the probability of sovereign default raises foreign demand for domestic bonds which, under a float, causes an appreciation of the exchange rate and a reduction in output. Under fixed exchange rates, however, the fiscal contraction and the associated reduction in sovereign risk do not result into an exchange rate appreciation and so the positive effects on private demand dominate, at least in the short run. In the long run, prices adjust upwards, which causes a decline in demand and off-sets the initial positive effects of the fiscal contraction. Hence, we find expansionary fiscal contractions to be feasible, yet only under fixed exchange rates and only in the short run.

The remainder of this paper is structured as follows. In the following section, we present empirical evidence that fiscal multipliers can be larger under flexible than fixed exchange rates in the presence of sovereign risk. In Section 3, we describe the model and its calibration. Results are presented and discussed in Section 4 and the implications of our results for the potential expansionary effects of fiscal consolidations are examined in Section 5. Finally, Section 6 concludes.

\section{An empirical assessment}

Recently, a number of empirical contributions has studied the influence of the economic environment on the effects of fiscal shocks on output, its main components and other policy-relevant variables (see, among others, Ilzetzki et al., 2012, Corsetti et al., 2012, and Auerbach and Gorodnichenko, 2012). Corsetti et al. (2012), 
for example, estimate the effects of a government spending shock on output under different monetary regimes. The authors report larger fiscal multipliers under fixed exchange rates than under flexible exchange rates, as one would expect based on the traditional Mundell-Fleming paradigm. In addition, the study considers the implications of weak public finances for the efficacy of fiscal policy and empirical estimates suggest that conditioning on high values of public debt (relative to output) reduces the effects of government spending on output.

However, the authors do not investigate whether the effects of the exchange rate regime on the efficacy of fiscal policy are different in countries with weak public finances. Recent episodes of sovereign risk suggest that conditioning the effects of fiscal policy on the monetary regime and the state of public finances simultaneously, rather than separately as in Corsetti et al. (2012), might be necessary. De Grauwe (2012), for example, compares substantial increases in government debt in the UK and Spain and finds that the economic consequences of these events have been very different across the two countries. In the UK, the rise in public debt was met by a depreciation of the nominal exchange rate, which supported exports and thus facilitated economic growth; in Spain, however, no such depreciation was able to take place and the rise in government debt was associated with a decline in output growth. Experiences from other OECD countries during 2007-11 tell a similar story: in countries with flexible exchange rates that faced sovereign risk (as measured by an increase in the sovereign credit default swap rate of at least 100 basis points), the nominal and real exchange rate depreciated (16\% and $7 \%$, respectively, on average compared to the OECD-mean) and, consequently, exports and output rose (5\% and $2 \%$, respectively). On the other hand, in countries with fixed exchange rates, the real exchange rate barely changed during episodes of sovereign risk ( $1 \%$ on average), while exports and output fell (both by $2 \%$ ).

As changes in sovereign default risk affect the exchange rate, exports and output, what then are the effects of a fiscal expansion in times of fiscal strain? Also, how do these effects depend on the exchange rate regime? In this section, we address these questions through an empirical assessment. In particular, we extend the analysis of Corsetti et al. (2012) by estimating the effects of government spending shocks conditional on both the monetary regime and the state of public finances.

We follow the two-step methodology suggested by Corsetti et al. (2012). In the first step, a relatively simple, country-specific government spending rule is estimated in order to identify the exogenous fiscal policy changes. Specifically, we estimate the following regression for each country $i$ :

$$
\begin{aligned}
\operatorname{GOVT}_{i t}= & \text { CONST }_{i}+\gamma_{i 1} \text { GOVT }_{i t-1}+\gamma_{i 2} \text { OUTPUT }_{i t-1}+\gamma_{i 3} \operatorname{CLI}_{i t-1} \\
& +\gamma_{i 4} \mathrm{DEBT}_{i t}+\gamma_{i 5} \mathrm{RISK}_{i t-1}+\gamma_{i 6} \mathrm{REGIME}_{i t-1}+\operatorname{INNOVATIONS}_{i t}(1)
\end{aligned}
$$

where GOVT $i t$ denotes the log of government consumption per capita at $t$, OUTPUT $_{i t}$ the log of gross domestic product (GDP) per capita, $\mathrm{CLI}_{i t-1}$ the composite leading indicator, $\mathrm{DEBT}_{i t}$ the debt-to-GDP ratio at the beginning of the period, $\mathrm{RISK}_{i t}$ is a dummy variable which indicates whether the corresponding country is facing sovereign risk, and $\mathrm{REGIME}_{i t}$ is a dummy indicating the monetary regime. The variable INNOVATIONS $i t$ is the estimation residual and serves as a proxy for the exogenous government spending shock. As in Corsetti et al. (2012), we use the 
implicit exchange rate regime classification as developed by Ilzetzki et al. (2010) to distinguish between monetary regimes ("flex" or "fixed"), while sovereign risk is assumed to be present whenever the debt-to-GDP ratio is larger than $100 \%$ and/or the budget deficit exceeds $6 \%$ of GDP in the previous year.

In the second step, we split the sample based on whether or not the country was facing sovereign risk. Then, for each sub-sample, we perform a fixed-effects panel regression on a number of macroeconomic variables using the (country-specific) residuals as explanatory variables. Specifically, for $\mathrm{VAR}_{i t}$ being the variable of interest, we estimate:

$$
\begin{aligned}
\operatorname{VAR}_{i t}= & \operatorname{CONST}_{i}+\beta_{i 1} \mathrm{VAR}_{i t-1}+\sum_{s=0}^{k} \beta_{2 s} \mathrm{INNOVATIONS}_{i t-s} \\
& +\sum_{s=0}^{k} \beta_{3 s} \mathrm{INNOVATIONS}_{i t-s} \times \mathrm{REGIME}_{i t-1}+\mathrm{ERROR}_{i t},
\end{aligned}
$$

where INNOVATIONS ${ }_{i t}$ are the residuals obtained from the first step. In Equation (2), the coefficient $\beta_{2 s}$ measures the unconditional fiscal multiplier of a government spending shock $s$ periods ago, whereas $\beta_{2 s}+\beta_{3 s}$ is the fiscal multiplier conditional on the regime classification. Following Corsetti et al. (2012), we set $k=3$. Data is from the OECD and the IMF. ${ }^{2}$

Using the estimated coefficients, we simulate the impulse responses of output and the real exchange rate upon a shock to government spending of $1 \%$ of output; the results are shown in Figure 1. The figures in the left column show the responses conditional on the exchange rate regime for the countries that did not face sovereign risk. This serves as a benchmark case. In line with the findings of Corsetti et al. (2012), the impact response of output is higher under fixed exchange rates than under flexible exchange rates. ${ }^{3}$ We then deviate from Corsetti et al.'s analysis by estimating the responses upon a government spending shock conditional on the monetary regime for only the countries facing sovereign risk. The results are shown in the right column of Figure 1. For the countries that were facing sovereign risk, we see that the output response is now higher under flexible exchange rates than under fixed rates, contrasting traditional Keynesian wisdom. Splitting the sample of countries according to their state of public finances therefore seems to be non-trivial when examining the efficacy of fiscal policy across monetary regimes. The results also show that the rise in government consumption in the presence of sovereign risk is accompanied by a significant depreciation (i.e. increase) of the real exchange rate in the 'flex' countries, whereas the real exchange rate depreciates only marginally in the 'fixed' countries. These contrasting exchange rate dynamics may explain the differences between output responses across monetary regimes.

The possible mechanism underlying the empirical findings, i.e. that fiscal multipliers under fiscal stress are higher under flexible than fixed exchange rates due to a depreciation (rather than an appreciation) of the exchange rate, is explained in

\footnotetext{
${ }^{2}$ Data was obtained from the OECD EO 92 data set, with the exception of government debt, which was obtained from IMF GFS whenever data points were missing. The panel contains 17 countries, covers 1970-2012 and is unbalanced.

${ }^{3}$ Our benchmark results differ slightly from those of Corsetti et al. (2012), as we use a larger sample and a more restrictive exchange rate regime classification.
} 
Figure 1: Responses to a government spending shock: empirical estimates
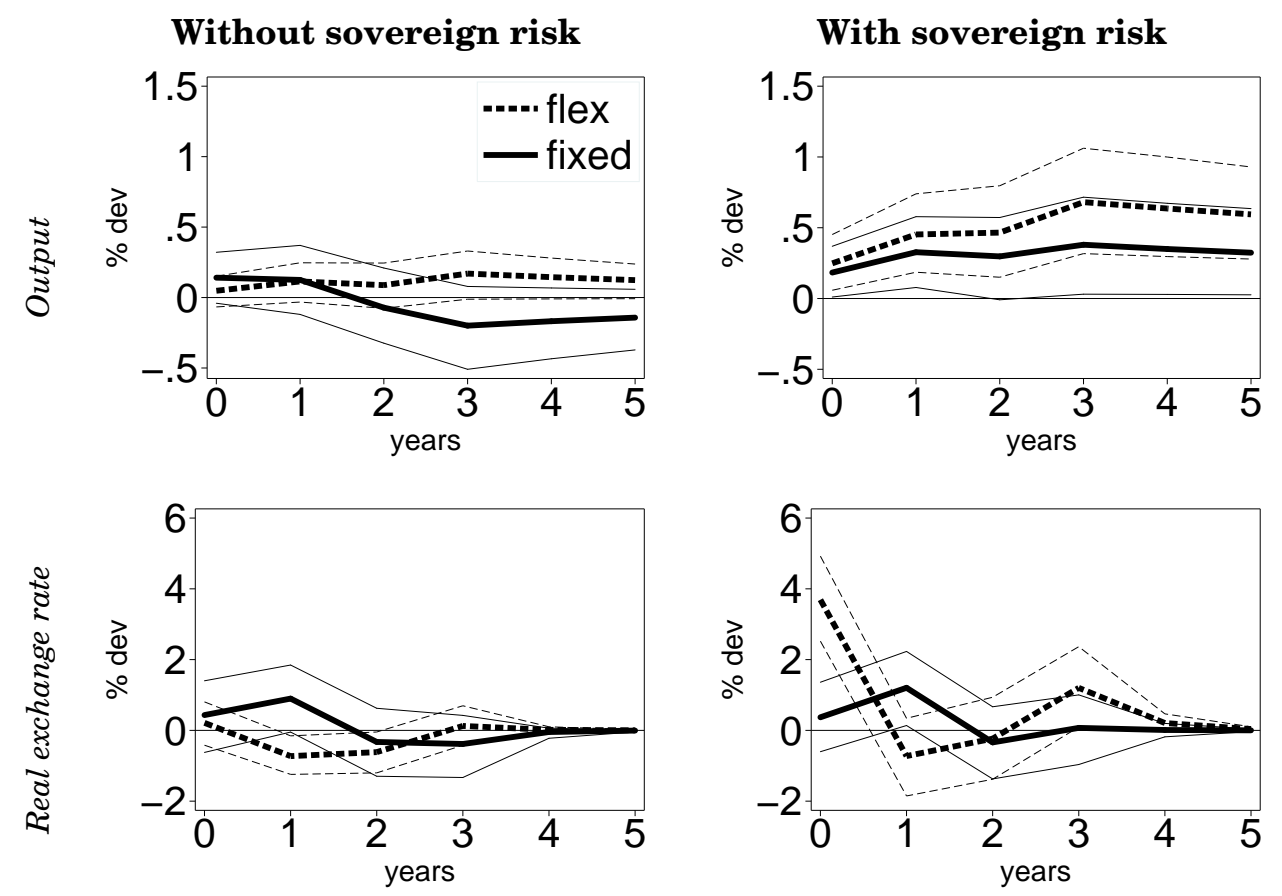

Notes: "Output" denotes the log of GDP per capita; "Real exchange rate" denotes the change in the real exchange rate; a positive (negative) change in the real exchange rate refers to a depreciation (appreciation).

the remainder of the paper using a modified version of the New Keynesian model. We shall explain the building blocks of this model in the following section.

\section{A New Keynesian model with sovereign risk}

Our model extends the New Keynesian small open economy model of Galí and Monacelli (2008) by introducing risky government debt and allowing for spillovers from sovereign default risk to private credit conditions. The model contains a continuum of small countries that interact on international goods and asset markets. We focus on one country, named "Home", whose small size implies the domestic economy does not exert a significant influence on the economies of the other countries, which we lump together under the heading "Foreign". Variables corresponding to Foreign are denoted by an asterisk superscript. In what follows, we shall describe the Home environment and index Home and Foreign variables by $H$ and $F$, respectively, where needed.

\subsection{The public sector}

The public sector consists of a fiscal authority ("government") and a monetary authority ("central bank"), who act independently from each other. The government consumes an amount $G_{t}$, levies lump-sum taxes, $T_{t}$, and issues one-period sovereign bonds, $B_{t}$, on which it pays a gross interest rate, $R_{t}$. The central bank sets the 
policy rate through the sale and purchase of government securities.

A key feature of the model is the government's ability to default on its debt obligations. A number of recent contributions have examined the implications of sovereign default risk for inflation and output volatility and the efficacy of monetary policy, e.g. Davig et al. (2010), and for the relationship between the debt-to-output ratio and interest rates, e.g. $\mathrm{Bi}(2012)$. In these studies, sovereign risk arises due to the presence of a so-called "fiscal limit", i.e. an upper bound to the level of government debt that is economically or politically feasible; beyond the fiscal limit, the government defaults. ${ }^{4}$ In the present model, we follow a similar approach. However, unlike in the aforementioned studies, which focus on the interaction between the economy and the fiscal limit and in which the limit is modelled endogenously, we assume the fiscal limit is determined exogenously. Particularly, since the focus of the paper is on the effects of government spending shocks on the economy in the presence of sovereign risk, regardless of how the economy evolves towards its fiscal limit, we require only the presence of such a limit.

To this end, we closely follow the sovereign default mechanism suggested by Schabert and van Wijnbergen (2011) who assume the fiscal limit reflects the maximum amount of outstanding real liabilities, say $\bar{b}$, the government is willing to service. ${ }^{5}$ As in Schabert and van Wijnbergen, $\bar{b}$ follows an exogenous process (driven, for example, by unobservable political sentiments) and is unknown ex ante to all agents. Upon maturity of each government bonds contract, the fiscal limit is drawn from a known distribution. If the current real debt burden exceeds the fiscal limit, the government fully defaults; otherwise, debt is fully repaid. Specifically, the sovereign's default scheme is defined as:

$$
\Delta_{t}=\left\{\begin{array}{lll}
0 & \text { if } & \frac{R_{t-1}}{\pi_{t}} b_{t-1} \leq \bar{b} \\
1 & \text { if } & \frac{R_{t-1}}{\pi_{t}} b_{t-1}>\bar{b}
\end{array},\right.
$$

where $\Delta_{t}$ is the ex post default indicator, $b_{t} \equiv B_{t} / P_{t}$ is the real value of government debt, with $P_{t}$ the consumer price index (CPI), and $\pi_{t} \equiv P_{t} / P_{t-1}$ the gross rate of inflation, such that $\left(R_{t-1} / \pi_{t}\right) b_{t-1}$ is the real value of total outstanding public liabilities. As agents know that the default decision is governed by (3) and since they are familiar with the distribution of the fiscal limit, they determine the ex ante probability of a sovereign default occurring at date $t$, denoted by $\delta_{t} \in[0,1)$, based on the probability that $\left(R_{t-1} / \pi_{t}\right) b_{t-1}$ exceeds the politically infeasible level $\bar{b}$ when debt repayment is due, i.e.

$$
\delta_{t}=E_{t-1} \Delta_{t}=\int_{0}^{\frac{R_{t-1}}{\pi_{t}} b_{t-1}} h(\bar{b}) d \bar{b}=H\left(\frac{R_{t-1}}{\pi_{t}} b_{t-1}\right),
$$

where $E_{t}$ is the expectations operator conditional on the information available at $t, h(\bar{b})$ is the probability density function of the fiscal limit and $H\left(\frac{R_{t-1}}{\pi_{t}} b_{t-1}\right)$ the

\footnotetext{
${ }^{4}$ See Eaton and Gersovitz (1981) for a political economy model in which the fiscal limit arises through strategic decisions by the government and $\mathrm{Bi}$ (2012) for an example in which the fiscal limit arises from the constraints imposed by the economy's Laffer curve on the sovereign's ability to service debt.

${ }^{5}$ As argued by Buiter and Rahbari (2013), it is the sovereign's willingness to repay sovereign debt which is the limiting factor that determines fiscal limits in most advanced economies, rather than the ability to repay.
} 
Figure 2: Distribution of the fiscal limit and determination of the default probability

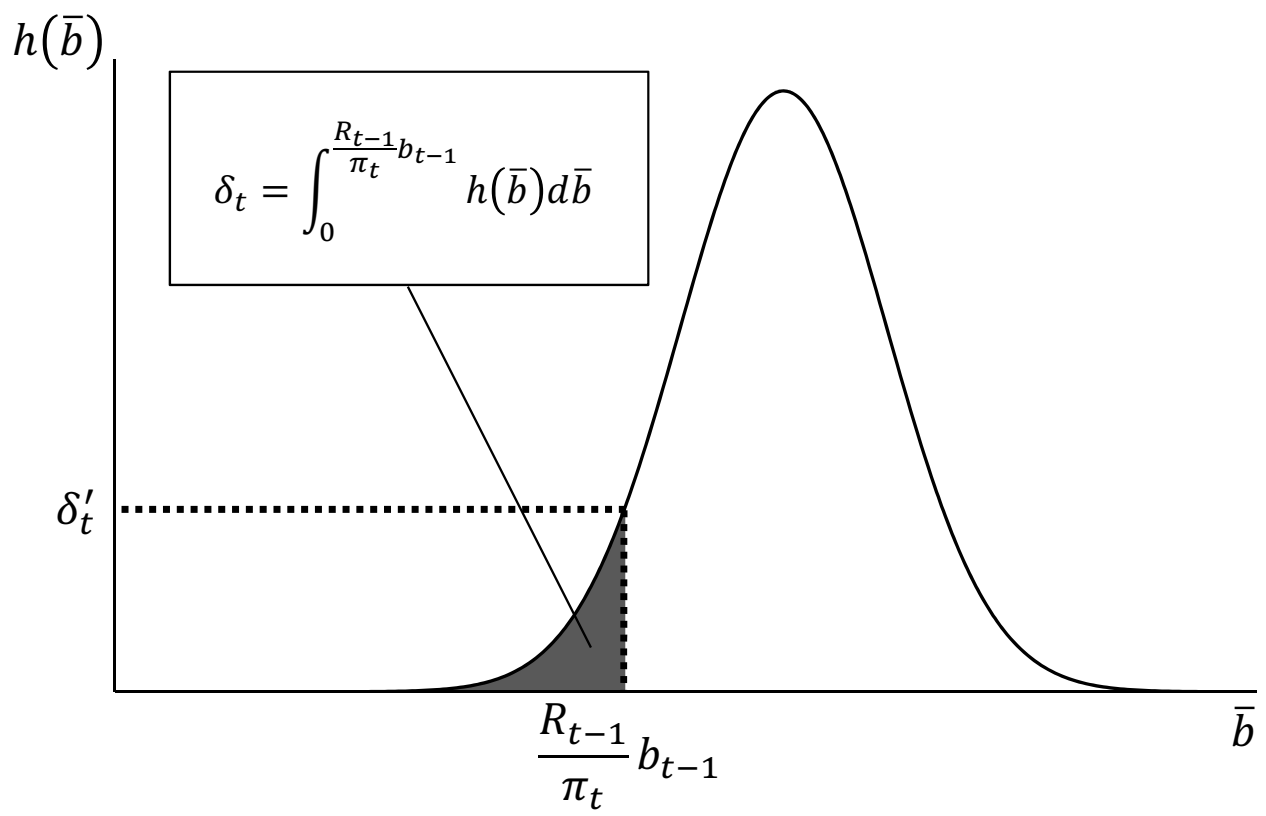

Notes: The fiscal limit is given by $\bar{b}$, whereas $\delta_{t} \in[0,1)$ denotes the default probability. Further, $\left(R_{t-1} / \pi_{t}\right) b_{t-1}$ are total real outstanding public liabilities and $\delta_{t}^{\prime}$ the derivative of $\delta_{t}$ with respect to $\left(R_{t-1} / \pi_{t}\right) b_{t-1}$.

associated distribution function. Following Schabert and van Wijnbergen (2011), we define the default elasticity, denoted by $\Phi$, as the product of the true default elasticity with respect to the real value of total debt evaluated at the steady state, $\delta^{\prime}(R / \pi) b / \delta$, and the ratio $\delta /(1-\delta)$. The parameter $\Phi$ indicates how much the default probability increases, and thus the effective return on government bonds decreases, for a given increase in the real debt burden. If $\Phi=0$, the bonds rate does not respond to changes in the debt level and thus sovereign risk is absent (even if $\delta>0$ ). Figure 2 plots $h(\bar{b})$ and highlights $\delta_{t}$ as the probability that $\bar{b}$ is drawn from the shaded area.

Government spending follows an exogenous AR(1) process, i.e.

$$
\ln \left(\frac{G_{t}}{G}\right)=\rho_{g} \ln \left(\frac{G_{t-1}}{G}\right)+\varepsilon_{t}^{g}
$$

where $G$ is the level of steady-state government consumption, $\rho_{g} \in[0,1]$ the autocorrelation coefficient of government spending and $\varepsilon_{t}^{g} \sim N\left(0, \sigma^{g}\right)$ a random i.i.d. government spending shock. For any given level of public expenditures, the government decides on the optimal allocation between consumption of domestically produced goods, $G_{H t}$, and imported goods, $G_{F t}$, using a standard CES aggregator. The corresponding demand schedules and the consumer price index are derived in Appendix A.1 and depend on the elasticity of substitution between domestic and foreign goods, $\eta>0$, and the degree of home bias in government consumption, $1-\alpha$, 
where $\alpha \in[0,1)$ measures the degree of country openness.

The government follows a relatively standard fiscal rule, given by:

$$
P_{t} T_{t}=\phi_{b} \frac{T}{b / \pi}\left(B_{t-1}-B\right)
$$

where the steady-state tax rate, $T$, is chosen to ensure a positive value for real debt in steady state, $b$, and where the parameter $\phi_{b}$ is set sufficiently large to prevent debt developments from being explosive. The government's perceived budget constraint then reads:

$$
B_{t}+P_{t} T_{t}=\left(1-\delta_{t}\right) R_{t-1} B_{t-1}+P_{t} G_{t}
$$

The central bank conducts monetary policy, assumed to be fully credible, by setting the nominal policy rate, $R_{t}-1$, which equals the interest rate on government bonds, through open market operations. ${ }^{6}$ Under a monetary regime of flexible exchange rates, the central bank follows a simple Taylor-type rule (Taylor, 1993), relating the policy rate to changes in expected inflation:

$$
\ln \left(\frac{R_{t}}{R}\right)=\rho_{r} \ln \left(\frac{R_{t-1}}{R}\right)+\left(1-\rho_{r}\right) \phi_{\pi} \frac{E_{t} \pi_{t+1}}{\pi},
$$

where $\rho_{r} \in[0,1]$ measures the degree of interest rate smoothing, $\phi_{\pi}$ is set sufficiently large to rule out price level indeterminacy and $R$ is the steady-state gross policy rate chosen such that stability of steady-state inflation, $\pi$, is guaranteed. Under a regime of fixed exchange rates, we assume the central bank commits to keep the nominal exchange rate, $e_{t}$, constant, i.e.

$$
e_{t}=e, \text { for all } t,
$$

through appropriate adjustments in the policy rate so as to satisfy the UIP condition (see below).

The assumption that the central bank controls the interest rate on government bonds implies that investors are unable to negotiate upon the rate of return and demand a risk premium as compensation for sovereign risk; they must therefore respond to changes in sovereign risk by adjusting their holdings of bonds, rather than adjusting the bonds price. We will revisit this assumption later on.

\subsection{Households}

Our infinitely lived, representative household consumes Home and Foreign goods, $C_{H t}$ and $C_{F t}$, respectively, is employed in the domestic economy and participates in international asset markets. It chooses the level of total consumption, $C_{t}$, and the amount of labour supply, $N_{t}$, in order to maximise expected lifetime utility, i.e.

$$
E_{0}\left[\sum_{k=0}^{\infty} \beta^{k}\left(\frac{C_{t+k}^{1-\sigma}}{1-\sigma}-\frac{N_{t+k}^{1+\varphi}}{1+\varphi}\right)\right],
$$

\footnotetext{
${ }^{6}$ Note that, if $\delta>0$, the policy rate is strictly larger than the risk-free interest rate (see Uribe, 2006).
} 
where $\beta \in(0,1)$ is the household's discount factor, $\sigma>0$ is the inverse of the intertemporal elasticity of substitution and $\varphi>0$ is the inverse of the Frisch elasticity of labour supply. The household's consumption allocation is governed by a similar CES function that aggregates public consumption; the demand schedules for $C_{H t}$ and $C_{F t}$ are derived in Appendix A.1. Furthermore, the household receives labour income, $W_{t} N_{t}$ with $W_{t}$ the nominal wage rate, and profits from intermediate goods firms, $\Psi_{t}=\int_{0}^{1} \Psi_{t}(i) d i$ where $i \in[0,1]$ is a firm-specific index, and pays lump-sum taxes, $T_{t}$, to the government. Finally, the household can borrow an amount $F_{t}^{*}$ from Foreign lenders and invest in domestic sovereign bonds, $B_{H t}$. The household must pay the world interest rate, $R_{t}^{*}-1$, times a risk premium, $\Xi_{t}^{*}$, on its external debt, whereas government bonds earn the domestic interest rate, $R_{t}-1$, conditional on the probability of sovereign default.

Another key feature of the model is that we allow for sovereign default risk to affect private borrowing conditions. Intuitively, an increase in sovereign risk might deteriorate the balance sheets of financial institutions who hold significant amounts of domestic government bonds, which raises the borrowing costs of these financial institutions and subsequently that of their clients (i.e. households and firms). ${ }^{7}$ Also, strained public finances may induce the government to significantly increase taxes, appropriate private property or even trigger a currency crisis; any such circumstances would make it more difficult for private borrowers to meet their liabilities, prompting lenders to demand a higher risk premium on private debt. ${ }^{8}$ Corsetti et al. (2013) model such credit market frictions in a New Keynesian model for a closed economy, in which loan origination costs create a spread between household lending and deposit rates. In their model, the authors consider a link between public and private sector borrowing conditions by assuming that the loan origination costs depend on the sovereign bonds spread. According to the authors, this link, or "sovereign risk channel", "captures the adverse effect of looming sovereign default risk on private-sector financial intermediation" (Corsetti et al., 2013, p. 105).

We take a similar approach as in Corsetti et al. (2013), yet rather than modelling explicitly a financial sector featuring credit frictions, we simply assume that the private risk premium is determined by a function which is monotonically increasing in the loss incurred by Foreign investors due to sovereign default, i.e. $\delta_{t} b_{F t}$, where $b_{F t} \equiv B_{F t} / P_{t}$ is the real value of government bonds held by Foreign. In particular, the sovereign risk channel is captured by the following reduced form expression:

$$
\Xi_{t}^{*}=\Xi_{t}^{* f} \Xi_{t}^{* b}=\exp \left(\chi_{1} \frac{f_{t}^{*} q_{t}}{Y}\right) \exp \left(\chi_{2} \frac{\delta_{t} b_{F t}}{Y}\right)
$$

where $f_{t}^{*} \equiv F_{t}^{*} / P_{t}^{*}$ are real net private external liabilities, $q_{t}$ is the real (effective) exchange rate and $Y$ the steady-state level of output.

\footnotetext{
${ }^{7}$ Angeloni and Wolff (2012) show that, during the recent European sovereign debt crisis, bank's holdings of Greek, Italian and Irish sovereign bonds had a material effect on their stock market value. Similarly, Demirgüç-Kunt and Huizinga (2013) report a reduction in bank's market-to-book value (and an increase in bank credit default swap spreads) in countries running large public deficits. Furthermore, Harjes (2011) and Acharya et al. (2011) show that sovereign credit costs were closely related to private funding costs during 2008-11 and 2007-10, respectively.

${ }^{8}$ Durbin and $\mathrm{Ng}$ (2005) find that bond spreads of firms in emerging market economies are usually higher than those of their home government. However, they also find that the reverse holds for firms with substantial earnings abroad, which cannot be taxed or appropriated by the home government.
} 
The coefficient $\chi_{1}>0$ measures the elasticity of the risk premium with respect to $f_{t}^{*} / Y$, whereas $\chi_{2}$ captures the strength of the pass-through between public and private credit risk. The sign restriction on $\chi_{1}$ is required for stability of the foreign asset position in a small open economy model with incomplete asset markets (see Schmitt-Grohé and Uribe, 2003, for details). The coefficient $\chi_{2}$ has no sign restrictions and allows us to isolate the effects of the sovereign risk channel. If $\chi_{2}=0$, the loss from sovereign default does not translate into higher private borrowing spreads and the private risk premium depends solely on outstanding private liabilities, i.e. $\Xi_{t}^{*}=\Xi_{t}^{* f}$. However, if $\chi_{2}>0$, an increase in the loss from sovereign default reduces household creditworthiness and hence raises the risk premium through an increase in $\Xi_{t}^{* b}$. We will refer to the change in private credit conditions that originates from a change in sovereign risk as "sovereign risk pass-through".

The household's (perceived) budget constraint is given by:

$$
B_{H t}+P_{t} C_{t}+P_{t} T_{t}+e_{t} \Xi_{t-1}^{*} R_{t-1}^{*} F_{t-1}^{*}=\left(1-\delta_{t}\right) R_{t-1} B_{H t-1}+e_{t} F_{t}^{*}+W_{t} N_{t}+P_{t} \Psi_{t} .
$$

Subject to (11) and an appropriate transversality condition and taking prices, taxes, firm profits, the wage rate, the sovereign default probability, the risk premium and initial asset holdings, $F_{-1}^{*}$ and $B_{H-1}$, as given, the household maximises (9), which leads to the following first-order conditions:

$$
\begin{aligned}
N_{t}^{\varphi} & =w_{t} C_{t}^{-\sigma}, \\
C_{t}^{-\sigma} & =\beta E_{t}\left[\frac{e_{t+1}}{e_{t}} \frac{R_{t}^{*}}{\pi_{t+1}} \Xi_{t}^{*} C_{t+1}^{-\sigma}\right], \\
C_{t}^{-\sigma} & =\beta E_{t}\left[\left(1-\delta_{t+1}\right) \frac{R_{t}}{\pi_{t+1}} C_{t+1}^{-\sigma}\right] .
\end{aligned}
$$

Equation (12) describes the household's optimal intratemporal decision, relating the marginal rate of substitution between consumption and leisure to the real wage rate, $w_{t} \equiv W_{t} / P_{t}$. Equations (13) and (14) determine the household's optimal level of external debt and holdings of domestic government bonds, respectively, by relating expected consumption growth to the (effective) real rate of return corresponding to the two assets.

Foreign households can invest in Home government bonds, $B_{F t}$, and loans to Home households, $F_{t}^{*}$. Assuming similar preferences as those of Home households, i.e. $\eta^{*}=\eta, \beta^{*}=\beta$ and $\sigma^{*}=\sigma$, the optimal intertemporal allocation is determined by the following two Euler conditions:

$$
\begin{aligned}
\left(C_{t}^{*}\right)^{-\sigma} & =\beta E_{t}\left[\left(C_{t+1}^{*}\right)^{-\sigma} \frac{R_{t}^{*}}{\pi_{t+1}^{*}} \Xi_{t}^{*}\right], \\
\left(C_{t}^{*}\right)^{-\sigma} & =\beta E_{t}\left[\left(C_{t+1}^{*}\right)^{-\sigma}\left(1-\delta_{t+1}\right) \frac{e_{t}}{e_{t+1}} \frac{R_{t}}{\pi_{t+1}^{*}}\right],
\end{aligned}
$$

where $\pi_{t}^{*} \equiv P_{t}^{*} / P_{t-1}^{*}$ is gross Foreign CPI inflation. Assuming constant Foreign consumption and inflation, the no-arbitrage condition that arises from the possibility to invest in both public and private debt is obtained by combining equations (15) and (16), i.e.:

$$
E_{t}\left[\left(1-\delta_{t+1}\right) \frac{e_{t}}{e_{t+1}} R_{t}\right]=R_{t}^{*} \Xi_{t}^{*}
$$


Equation (17) is a variant of the UIP condition and implies that the effective rate of return on the domestic government bond and the Foreign discount bond must be the same.

\subsection{Firms}

The production sector consists of two types of firms: final goods firms, operating in perfectly competitive markets, and intermediate goods firms, operating in monopolistically competitive markets.

Final goods firms combine intermediate goods to produce the final good, $Y_{t}$, using a standard CES production function with $\epsilon>1$ the constant elasticity of substitution between intermediate goods. Minimisation of the costs of assembling $Y_{t}$, subject to the production technology, results in the optimal demand schedule for goods produced by intermediate goods firm $i, Y_{t}(i)$, and the aggregate domestic price level, $P_{H t}$, i.e.:

$$
\begin{aligned}
Y_{t}(i) & =\left[\frac{P_{H t}(i)}{P_{H t}}\right]^{-\epsilon} Y_{t}, \\
P_{H t} & =\left[\int_{0}^{1} P_{H t}(i)^{1-\epsilon} d i\right]^{\frac{1}{1-\epsilon}} .
\end{aligned}
$$

Intermediate goods firms, on the other hand, use the following linear, constant returns to scale production technology with only labour as an input factor in the production process:

$$
Y_{t}(i)=N_{t}(i)
$$

Optimal labour demand satisfies

$$
m c_{t}(i)=\frac{P_{t}}{P_{H t}} w_{t}
$$

where $m c_{t}(i)$ denotes real marginal costs. Nominal rigidities are introduced in the prices of intermediate goods by assuming staggered price setting (Calvo, 1983). Specifically, in every period, a randomly selected portion of intermediate goods firms, $1-\theta$, is able to adjust prices in response to demand and supply shocks, while the remaining share, $\theta \in[0,1)$, is unable to adjust and keeps prices unchanged. Hence, the parameter $\theta$, which is independent of the time elapsed since the previous price setting, is a measure of price rigidity and the average duration of a 'price contract' is $\sum_{k=0}^{\infty} \theta^{k} \Rightarrow 1 /(1-\theta)$. Firms that are able to adjust prices do so with the aim of maximising current and expected future profits, discounted by

the household's stochastic discount factor, $Q_{t, t+k} \equiv \beta^{k}\left(1-\delta_{t+k}\right)\left(\frac{C_{t+k}}{C_{t}}\right)^{-\sigma} / \pi_{t+k}$ (see [14]), and subject to (18) and (20), while taking the wage rate and the probability of non-price adjustment as given. The resulting optimal re-set price, $\bar{P}_{H t}$, is then a mark-up $\mathcal{M} \equiv \epsilon /(\epsilon-1)$ over current and expected real marginal costs, i.e.:

$$
\bar{P}_{H t}=\mathcal{M} \frac{E_{0} \sum_{k=0}^{\infty}(\theta \beta)^{k}\left(1-\delta_{t+k}\right) P_{t+k}^{-1} P_{H t+k}^{1+\epsilon} C_{t+k}^{-\sigma} Y_{t+k} m c_{t+k}}{E_{0} \sum_{k=0}^{\infty}(\theta \beta)^{k}\left(1-\delta_{t+k}\right) P_{t+k}^{-1} P_{H t+k}^{\epsilon} C_{t+k}^{-\sigma} Y_{t+k}} .
$$

Note that, under flexible prices, $\theta \rightarrow 0$ and $\bar{P}_{H t}=P_{H t}$ for all $t$, such that (22) reduces to $m c_{t}=1 / \mathcal{M}$. 


\subsection{Market clearing}

In equilibrium, all markets clear and the balance of payments holds. To facilitate the discussion, we first define international prices. The real (effective) exchange rate is defined as $q_{t} \equiv e_{t} P_{t}^{*} / P_{t}$. Since Home is a small country, its weight in Foreign's CPI is negligible and so $P_{F t}^{*}=P_{t}^{*}$. Furthermore, we assume that the 'law of one price' holds, such that $P_{H t}=e_{t} P_{H t}^{*}$ and $P_{F t}=e_{t} P_{F t}^{*}$.

Bonds market clearing implies:

$$
B_{t}=B_{H t}+B_{F t} .
$$

To clear the bonds market, an additional condition is required that reflects how domestic bond holders behave vis-à-vis foreign bond holders. We choose $B_{H t}=B_{H}$ to reflect the fact that foreign bond holders are typically more responsive to shocks to the domestic economy than their domestic counterparts (due to, for instance, exchange rate risk and the inability to perfectly insure against such macroeconomic risks).

Goods market clearing implies $Y_{t}=C_{H t}+G_{H t}+C_{H t}^{*}$. After substituting in the demand schedules, derived in Appendix A.1, one obtains:

$$
Y_{t}=(1-\alpha)\left(\frac{P_{H t}}{P_{t}}\right)^{-\eta}\left(C_{t}+G_{t}\right)+q_{t}^{\eta^{*}} \alpha^{*}\left(\frac{P_{H t}}{P_{t}}\right)^{-\eta^{*}} C_{t}^{*} .
$$

As derived in Appendix A.2, the expression for Home's exports, $X_{t}$, is given by:

$$
X_{t}=\alpha^{*}\left(\frac{q_{t}^{\eta-1}-\alpha}{1-\alpha}\right)^{\frac{\eta^{*}}{\eta-1}} C_{t}^{*} .
$$

Labour market clearing implies $N_{t}=\int_{0}^{1} N_{t}(i) d i$. Substituting in the intermediary goods firm's production technology, $Y_{t}(i)=N_{t}(i)$, and the final good firm's optimal demand schedule, $Y_{t}(i)=\left(P_{H t} / P_{t}\right)^{-\epsilon} Y_{t}$, we can write:

$$
N_{t}=Y_{t} Z_{t}=Y_{t}
$$

where $Z_{t} \equiv \int_{0}^{1}\left[\frac{P_{t}(i)}{P_{t}}\right]^{-\epsilon}$ is a measure of price dispersion whose equilibrium variations around a perfect foresight steady state are of second order, i.e. $Z_{t} \approx 1$ (see Galí and Monacelli, 2005).

Finally, the balance of payments condition follows from consolidating the government's and household's budget constraints, (6) and (11), respectively, substituting for aggregate firm profits, $P_{t} \Psi_{t}=P_{H t} Y_{t}-W_{t} N_{t}$, and the labour market clearing condition (26):

$$
\frac{P_{H t}}{P_{t}} Y_{t}-C_{t}-G_{t}=q_{t}\left(\frac{R_{t-1}^{*}}{\pi_{t}^{*}} \Xi_{t-1}^{*} f_{t-1}^{*}-f_{t}^{*}\right)+\left(1-\delta_{t}\right) \frac{R_{t-1}}{\pi_{t}} b_{F t-1}-b_{F t} .
$$

Equation (27) indicates that national savings must equal net capital outflow. 


\subsection{Steady state and equilibrium}

Given constant private consumption in steady state, i.e. $C_{t}=C$, Equation (14) implies that the steady-state gross real interest rate, $R / \pi$, is determined by $1 /[\beta(1-\delta)]$. Furthermore, (13) implies $R^{*} / \pi^{*}=1 /\left(\beta \Xi^{*}\right)$. Also, in the steady-state equilibrium, $\theta=0$ and $P_{H t}^{*}=P_{H t}$, such that $w_{t}=w=1 / \mathcal{M}$ by (21) and (22). Finally, we assume that Foreign and Home prices are the same in steady state, such that $e=q=1$.

Equilibrium is then given by a sequence of $C_{t+k}, N_{t+k}, Y_{t+k}, X_{t+k}, w_{t+k}, b_{t+k}$, $b_{F t+k}, f_{t+k}^{*}, \pi_{t+k}, \pi_{H t+k}, q_{t+k}, e_{t+k}, R_{t+k}, \Xi_{t+k}^{*}, \delta_{t+k}$ and $T_{t+k}$ satisfying the household's first-order conditions, (12), (13) and (14), and budget constraint (11), the UIP condition (17), the private risk premium condition (10), the price indices, (19) and (33), the intermediary goods firm's pricing decision (22), the public's budget constraint (6), the default scheme (3), the policy rules, (5) and (7) or (8), an exogenous sequence for government spending, (4), and the market clearing conditions, (23), (24), (26) and (27), given sequences for $C_{t+k}^{*}, R_{t+k}^{*}$ and $\pi_{t+k}^{*}$, for all $k$.

\subsection{Calibration}

We calibrate the model based on a quarterly frequency. For those parameters whose iterations have no qualitative effects on our results, i.e. $\sigma, \varphi, \beta, \eta$ and $\theta$, we follow the settings that are most commonly found in the literature (see Table 1). In what follows, we elaborate on the calibration of those parameters that can be expected to influence our main results and the equilibrium properties of the linearised model.

As explained in Section 2, we suspect sovereign risk to (positively) affect exports through changes in the exchange rate. The parameters relevant for the strength of this "exchange rate effect" are $\eta^{*}$, which measures Foreign's elasticity of substitution between Home and Foreign goods, and $\alpha$, which determines country openness. As a benchmark, we set $\eta^{*}=\eta=1$ and choose $\alpha=0.3$. We shall, however, experiment with alternative values for $\eta^{*}$ and $\alpha$ to test for the robustness of our results and to better understand the fiscal transmission mechanism.

The steady-state parameters are either based on data from OECD countries or determined implicitly by the equilibrium conditions given in Section 3.5. The steady-state share of government consumption in total output is set to $G / Y=0.2$, while the ratio of government debt and output in steady state is set to $b /(4 Y)=0.6$ (on an annual basis). We assume that $50 \%$ of all government debt is held by Foreign investors, i.e. $b_{F} / b=0.5$, which corresponds to the share of public debt held by non-residents in advanced economies (see Andritzky, 2012); thus, $b_{F} /(4 Y)=0.3$. Based on long-term data on total household loans, and assuming that the share of private debt held by foreign investors equals $b_{F} / b$, we calculate private external debt as a share of output as $f^{*} /(4 Y)=0.3$. Then, using the balance of payments condition, (27), total household consumption as a share of output is calculated as $C / Y=0.8$. Since Home is relatively small, we set the share of Home goods in Foreign consumption at $\alpha^{*}=0.01$. Total Foreign consumption as a share of Home output can then be calculated using the goods market clearing condition, (24), as $C^{*} / Y=30$, from which it follows that the export-to-output ratio is $X / Y=0.3$. Further, the steady-state tax-to-output ratio, which is implied by the government's budget constraint, (6), is calculated as $T / Y=0.2$. 
Table 1: Benchmark calibration

\begin{tabular}{lll}
\hline & Preference and production parameters & Value \\
\hline$\sigma$ & Inverse of the intertemporal elasticity of substitution & 0.5 \\
$\varphi$ & Inverse of the Frisch elasticity of labour supply & 1 \\
$\beta$ & Subjective discount factor & 0.99 \\
$\eta$ & Elasticity of substitution between Foreign and Home goods & 1 \\
$\alpha$ & Country openness & 0.3 \\
$\alpha^{*}$ & Foreign's openness with respect to Home & 0.01 \\
$\theta$ & Probability of non-price adjustment & 0.75 \\
\hline & Steady states & Value \\
\hline$G / Y$ & Government consumption as a share of output & 0.2 \\
$C / Y$ & Household consumption as a share of output & 0.8 \\
$C^{*} / Y$ & Foreign consumption as a share of output & 30 \\
$X / Y$ & Exports as a share of output & 0.3 \\
$b / Y$ & Real government debt as a share of output & 2.4 \\
$b_{F} / Y$ & Real government debt held by Foreign as a share of output & 1.2 \\
$f^{*} / Y$ & Real household external debt as a share of output & 1.2 \\
$T / Y$ & Taxes as a share of output & 0.2 \\
\hline & Policy parameters & Value \\
\hline$\phi_{\pi}$ & Monetary policy rule coefficient & 1.5 \\
$\rho_{r}$ & Nominal interest rate smoothing parameter & 0.7 \\
$\phi_{b}$ & Fiscal policy rule coefficient & 0.15 \\
$\rho_{g}$ & Persistence in government spending shocks & 0.9 \\
\hline & Sovereign risk and capital market imperfection & Value \\
\hline$\delta$ & Sovereign default probability & 0.0025 \\
$\Phi$ & Sovereign default elasticity & 0.03 \\
$\chi_{1}$ & Risk premium elasticity w.r.t. household net foreign debt & 0.0017 \\
$\chi_{2}$ & Degree of sovereign risk pass-through & 0.13 \\
\hline & &
\end{tabular}


Regarding the policy parameters, we set the Taylor rule parameter equal to the customary value of $\phi_{\pi}=1.5$ (such that the central bank obeys the Taylor-principle) and the interest rate smoothing parameter to $\rho_{r}=0.7$. The feedback between taxes and real government debt is set to $\phi_{b}=0.15$, roughly in line with estimates of Ballabriga and Martinez-Mongay (2010) for Euro area countries and ensuring that the debt level remains bounded (see Bohn, 1998), while the autocorrelation coefficient of government consumption is set to $\rho_{g}=0.9$, as e.g. in Galí et al. (2007).

The central parameters in our model are those governing sovereign risk, $\delta$ and $\Phi$, and capital market imperfections, $\chi_{1}$ and $\chi_{2}$. We assume the Home economy faces an annual government bonds spread of $1 \%$, which corresponds to a sovereign credit rating of $\mathrm{BB}$ at S\&P and Fitch and Ba at Moody's (see Table 3.1 in IMF, 2010) and implies a steady-state probability of sovereign default of $\delta=0.0025$. The default elasticity, $\Phi$, measures the response of the default probability to changes in the outstanding stock of real gross public debt. We rely on estimates reported by Cottarelli and Jaramillo (2012), who examine the effects of gross debt on sovereign credit default swap spreads for a number of advanced economies in 2011. Based on their estimation of $\delta^{\prime}=0.01$, we set $\Phi=0.03$. Since estimates on $\delta^{\prime}$ differ somewhat across studies (see e.g. Ardagna et al., 2007, and Laubach, 2009), we experiment with alternative values for $\Phi$ to check for robustness. Further, following Bouakez and Eyquem (2012), who rely on estimates of Lane and Milesi-Ferretti (2002), we set the elasticity of the private risk premium with respect to changes in household net external debt to $\chi_{1}=0.0017$. Finally, we assume that $15 \%$ of an increase in the default probability is transmitted to the risk premium on household loans (for empirical estimates of the degree of sovereign risk pass-through, see Albertazzi et al., 2012, and Zoli, 2013, among others). Using Equation (10), this implies $\chi_{2}=$ 0.13 . However, as in the case of the default elasticity parameter, we check for robustness of our results by varying the degree of sovereign risk pass-through.

\section{The effects of government spending shocks}

In this section, we discuss the economic effects of a government spending shock (of $1 \%$ of output) based on the impulse response functions generated by the loglinearised version of the model. ${ }^{9}$ We start by discussing the benchmark case without sovereign risk in order to reconcile our results with conventional Keynesian predictions and recent studies on the effects of fiscal policy (e.g. Corsetti et al., 2011, and Coenen et al., 2012). We then proceed by discussing how the results change when we allow for sovereign risk (Section 4.2) and spillovers from public to private borrowing costs (Section 4.3).

\subsection{Benchmark case: no sovereign risk}

The responses of output, the real exchange rate, exports and consumption are shown in Figure 3, whereas the responses of the nominal exchange rate, the nominal interest rate, the effective real rate of return on government bonds and the

\footnotetext{
${ }^{9}$ The full log-linearised version of the model is derived in Appendix B and is given by equations (39), (40) and (42) - (54). Throughout, we have assumed that Foreign consumption and inflation and the Foreign nominal interest rate remain constant, i.e. $C_{t}^{*}=C^{*}, \pi_{t}^{*}=\pi^{*}$ and $R_{t}^{*}=R^{*}$ for all $t$.
} 
private risk premium are shown by Figure $4 .{ }^{10}$ We start by focussing on the first column of both figures, which shows the effects of a government spending shock in the absence of sovereign risk. We find that an exogenous increase in government spending has a positive effect on output under both flexible and fixed exchange rates, yet the output response is (somewhat) larger under fixed exchange rates.

Driving these results are the responses of the (nominal and real) exchange rate, exports and household consumption. Particularly, the rise in government spending raises CPI inflation, which, under flexible exchange rates, induces the central bank to raise the nominal interest rate by the implied Taylor rule. The higher interest rate leads to a fall (i.e. appreciation) of both the nominal and real exchange rate, which reduces exports and dampens the increase in output (note that the nominal exchange rate depreciates after two quarters, due to a gradual lowering of the nominal interest rate by the central bank). Furthermore, since households expect an increase in (future) taxes and aim to smooth changes in future net income, private consumption falls below steady state. The net effect of government spending on output is positive, however, since the rise in public demand dominates the fall in private demand. Under fixed exchange rates, the rise in CPI inflation is followed by a more gradual appreciation of the real exchange rate, whereas, by construction, the nominal exchange rate remains constant at steady state. The crowding-out effects on exports following the fiscal expansion are thus reduced and the response of output to the fiscal shock is stronger under fixed than under flexible exchange rates.

The output responses under the benchmark case are in line with conventional Keynesian wisdom. Also, the predicted larger size of the fiscal multiplier in economies with fixed exchange rates has recently been reconfirmed empirically by Ilzetzki et al. (2012) and Corsetti et al. (2012). Note, however, that the differences in output responses across monetary regimes are much smaller than predicted by the traditional Mundell-Fleming model, yet correspond to the theoretical results shown in Corsetti et al. (2011) and empirical findings reported by Born et al. (2013). Also, the consumption responses shown in Figure 3 are not always in line with empirical evidence, which typically shows household consumption responds positively upon a positive government spending shock, rather than negatively. This inconsistency is a feature often found in basic New Keynesian models and has provoked many to find methods in order to better match theory with empirics. ${ }^{11}$ In this paper, we do not apply such methods to the model, as we are mainly interested in how sovereign risk affects the (relative size of the) fiscal multiplier, which, as shall be explained in further detail below, depends largely on the response of the exchange rate and to a lesser extent on the response of household consumption.

We now turn to the case where the economy is facing sovereign risk.

\subsection{Introducing sovereign risk}

In the presence of sovereign risk, the dynamics following a positive government spending shock differ markedly from the benchmark case (see the middle column of Figures 3 and 4). Most notably, an increase in government spending raises output under both monetary regimes, yet the rise in output is larger under a flexible

\footnotetext{
${ }^{10}$ The responses of the remaining variables are available upon request.

${ }^{11}$ See Galí et al. (2007) and Hebous (2011) for a discussion.
} 
Figure 3: Economic effects of a positive government spending shock
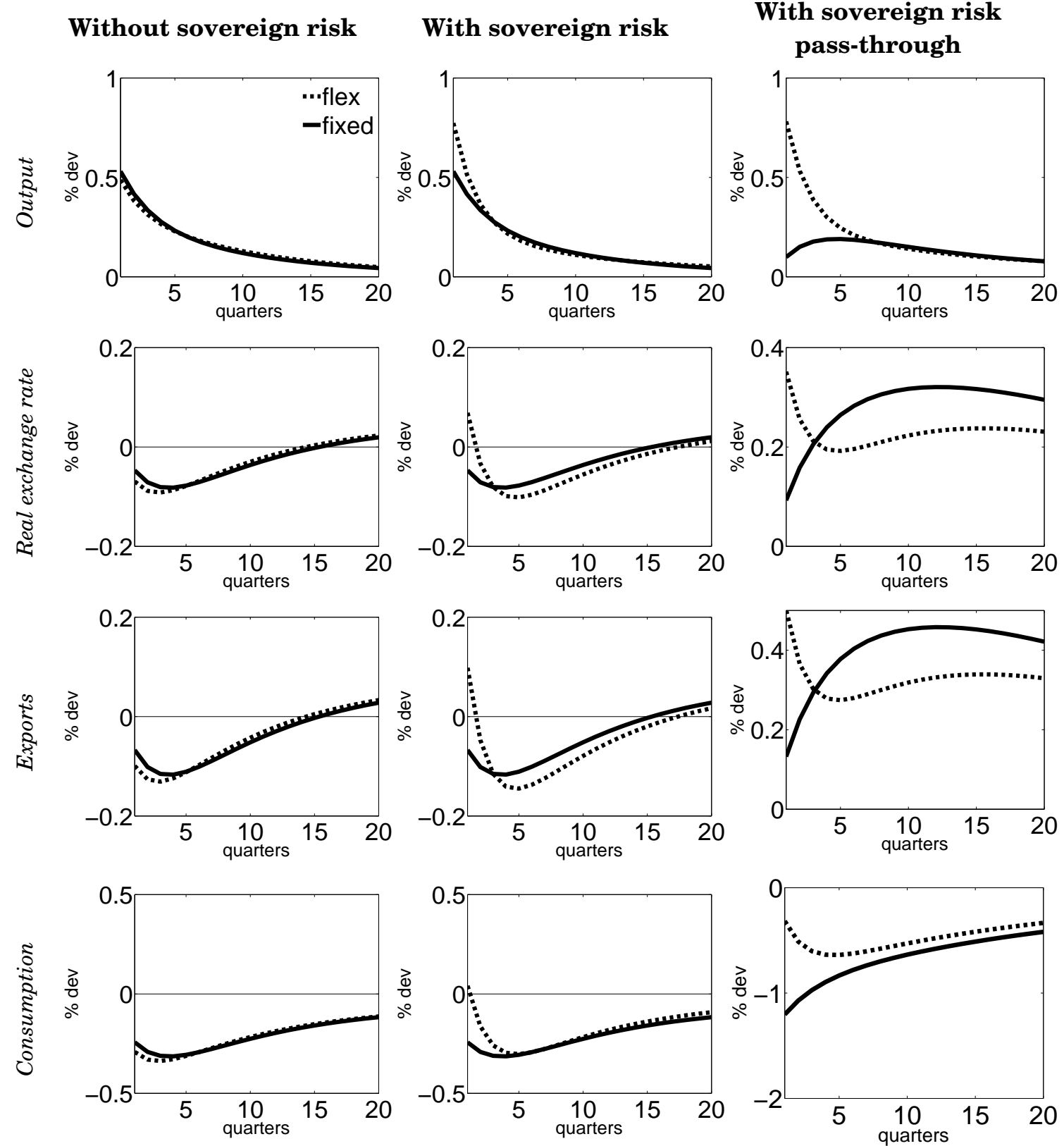

Notes: Figures show the impulse responses upon an exogenous increase in government spending (of $1 \%$ of output) from steady state. 
Figure 4: Economic effects of a positive government spending shock

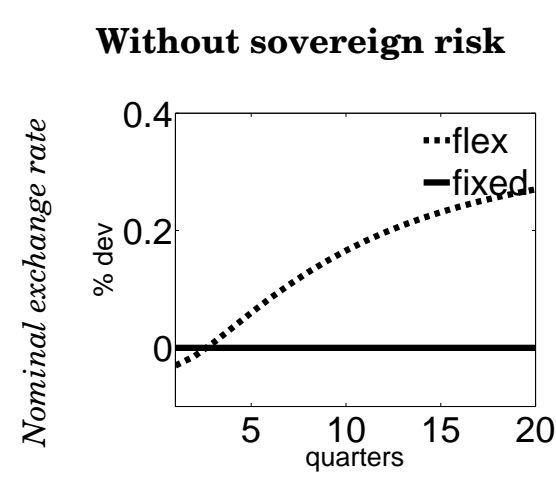

With sovereign risk
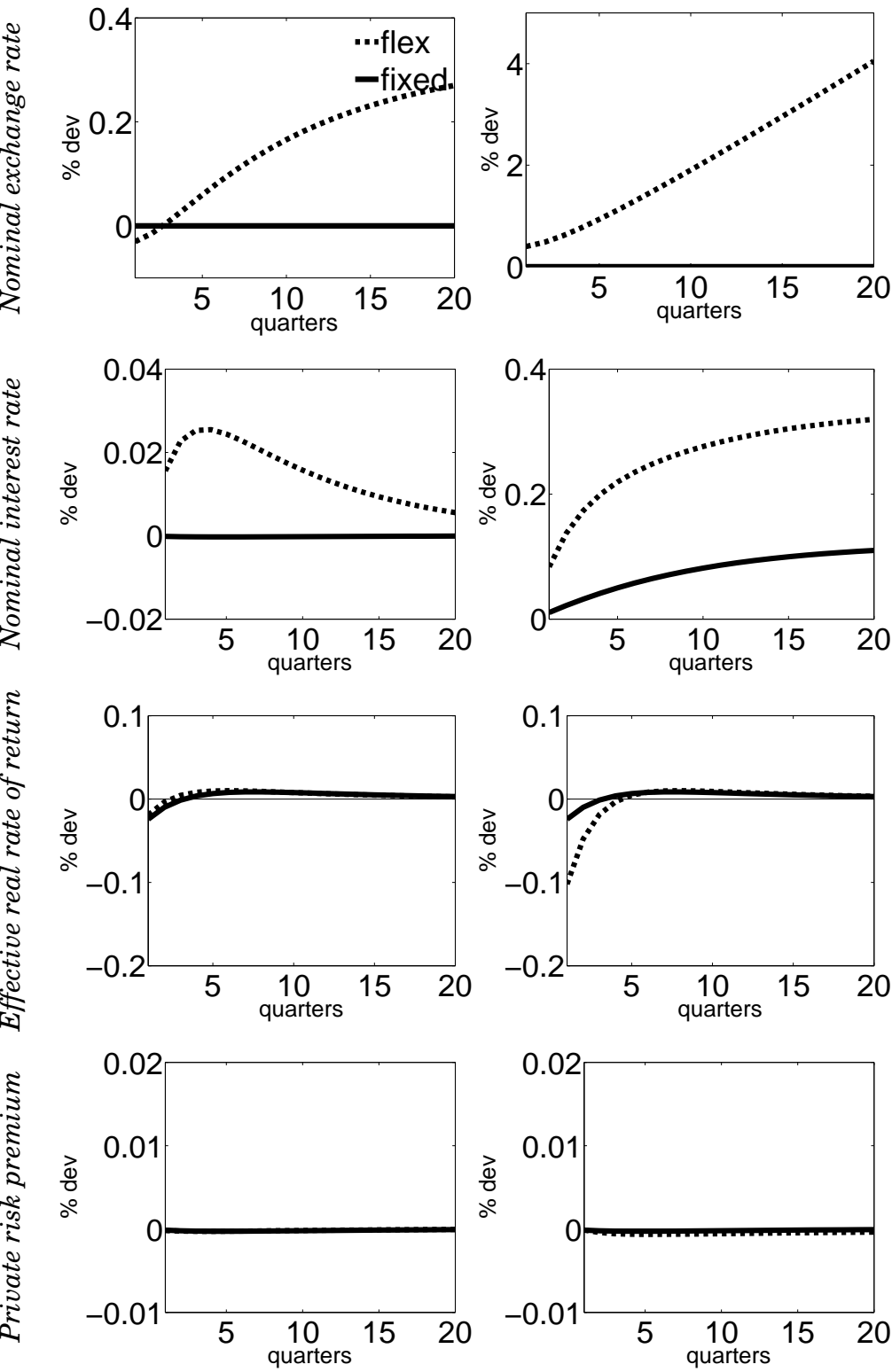

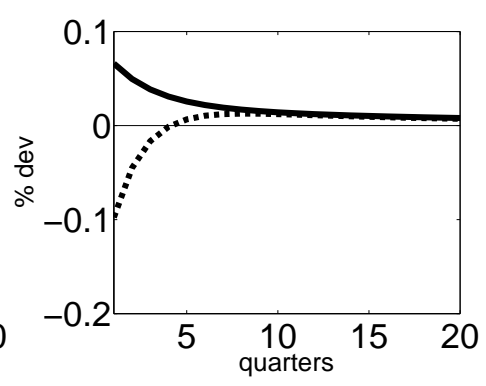

With sovereign risk pass-through
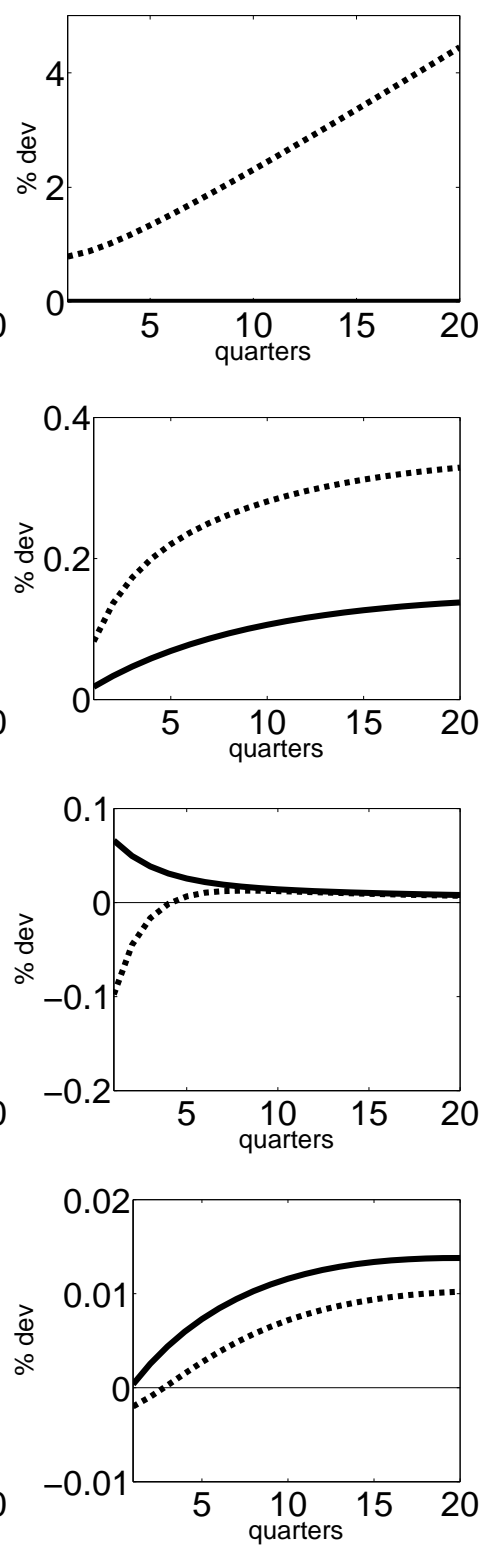

Notes: See notes under Figure 3. 
than under a fixed exchange rate regime, which stands in contrast to conventional Keynesian wisdom. This result is driven by a depreciation of the real exchange rate and the consequent rise in exports under flexible exchange rates, versus an appreciation of the real exchange rate and fall in exports under fixed exchange rates. In this section, we focus on the factors driving these results, in particular on the responses of the real exchange rate and exports.

We start by discussing the effects of sovereign risk on the exchange rate. When public debt is near the fiscal limit, a fiscal expansion worsens the state of public finances and generates sovereign default beliefs, i.e. $E_{t} \delta_{t+1}$ rises. The effective real rate of return on government bonds, $\left(1-E_{t} \delta_{t+1}\right)\left(R_{t} / E_{t} \pi_{t+1}\right)$, then falls, causing foreign investors to reduce their holdings of bonds. Under a floating exchange rate regime, an immediate depreciation of the exchange rate must follow to maintain equilibrium in the balance of payments. Figures 3 and 4 show that, compared to the benchmark case without sovereign risk, the nominal exchange rate now depreciates on impact, causing the real exchange rate to depreciate as well. Under fixed exchange rates, the central bank is forced to offset the rise in sovereign risk, and keep the return on government bonds fixed, so as to satisfy the UIP condition. As shown by Figure 4, the nominal interest rate therefore rises, such that the response of the effective real rate of return on government bonds is the same as in the benchmark case. Thus, a fiscal expansion leads to a depreciation of the real exchange rate under a float and to an appreciation under a peg. Note that the nominal interest rate rises by more under flexible than under fixed exchange rates, since the central bank cannot respond to inflation under the latter regime. Yet, despite the higher nominal interest rate, the effective real rate of return still falls under the floating exchange rate regime due to the rise in sovereign risk (which has not been offset by monetary policy).

The response of the real exchange rate to a government spending shock can be shown using the UIP condition, iterated forward and log-linearised:

$$
\hat{q}_{t}=\lim _{s \rightarrow \infty} E_{t} \hat{q}_{t+s}-E_{t} \sum_{j=0}^{\infty}\left[(1-\Phi)\left(\hat{R}_{t+j}-\hat{\pi}_{t+1+j}\right)-\Phi \hat{b}_{t+j}\right]+E_{t} \sum_{j=0}^{\infty} \hat{\Xi}_{t+j}^{*},
$$

where variables with a hat express the percentage deviation of that variable from its steady-state level. The net effect of a transitory increase in government spending on the real exchange rate, $\hat{q}_{t}$, depends on the responses of the real interest rate, $E_{t} \sum_{j=0}^{\infty}\left(\hat{R}_{t+j}-\hat{\pi}_{t+1+j}\right)$, and the change in sovereign risk, $E_{t} \sum_{j=0}^{\infty} \hat{b}_{t+j}$, which together comprise the effective real rate of return. ${ }^{12}$ The former is determined by the aggressiveness with which the central bank responds to inflation, $\phi_{\pi}$, while the latter is determined by the default elasticity with respect to outstanding government liabilities, $\Phi$. A higher real interest rate raises the return on bonds and causes an appreciation of the exchange rate; conversely, a rise in sovereign risk reduces the return on bonds and causes an exchange rate depreciation. Under flexible exchange rates, the immediate response of $\hat{q}_{t}$ is positive, provided $\Phi$ is sufficiently large relative to $\phi_{\pi}$. Under fixed exchange rates, the term $\Phi E_{t} \sum_{j=0}^{\infty} \hat{b}_{t+j}$ drops out

\footnotetext{
${ }^{12}$ Note that $\lim _{s \rightarrow \infty} E_{t} \hat{q}_{t+s}=0$ for transitory shocks and that the private risk premium, $E_{t} \sum_{j=0}^{\infty} \hat{\Xi}_{t+j}^{*}$, is not affected directly by a rise in government debt, since, for now, we have assumed $\chi_{2}=0$. Also, as shown by Figure 4 , the risk premium hardly changes following the government spending shock.
} 
of Equation (28) and, due to the rise in CPI inflation at $t$, the response of $\hat{q}_{t}$ is unambiguously negative. In fact, under fixed exchange rates (and absent sovereign risk pass-through), the responses of the endogenous variables are identical to the benchmark case, as sovereign risk can be eliminated from the model's dynamic equations and therefore has no effect on the economy. ${ }^{13}$

The response of the real exchange rate following the government spending shock determines the differences in output responses across the two monetary regimes. The depreciation of the real exchange rate under flexible exchange rates leads to an increase in exports and output. Under fixed exchange rates, however, the central bank completely off-sets the effects of sovereign risk, such that, as in the benchmark case, exports fall following the fiscal expansion. We refer to this effect as the "exchange rate effect".

We now turn to the response of exports. The depreciation of the real exchange rate under a float makes Home goods cheaper, as compared to Foreign goods, and thus exports rise. Indeed, the log-linearised version of Equation (25) shows that changes in exports from steady state, $\hat{X}_{t}$, equal changes in $\hat{q}_{t}$, times a constant:

$$
\hat{X}_{t}=\frac{\eta^{*}}{1-\alpha} \hat{q}_{t}
$$

Since $\eta^{*}>0$ and $\alpha \in[0,1)$, exports are increasing in $\hat{q}_{t}$. Recall that the parameter $\eta^{*}$ determines the responsiveness of Foreign demand for Home goods to changes in the (relative) price of Home goods. As the real exchange rate depreciates, Foreign demand for Home goods rises, and more so for a higher value of $\eta^{*}$, thereby leading to higher exports. Further, the parameter $\alpha$ determines the openness of the economy; if $\alpha$ is large, such that the economy is more open to foreign trade, the production sector benefits more from a depreciation of the real exchange rate. One would therefore expect the exchange rate effect to be stronger for larger values of $\eta^{*}$ and $\alpha$. To see whether this is the case, we plot the difference in output responses between the flexible and fixed exchange rate regime as a function of $\eta^{*}$ and $\alpha$. The results, presented in Figure 5, show that indeed the difference in output responses is increasing in both parameters.

The strength of the exchange rate effect further depends on the degree of sovereign risk, which is determined by $\Phi$ : for higher values of $\Phi$, a government spending shock exerts a stronger effect on the real exchange rate and, subsequently, on exports and output, yet only under flexible exchange rates. In Figure 8 in the Appendix, we vary $\Phi$, while keeping the other parameters fixed at their benchmark values, and find that the difference in the output response upon a government spending shock between the flexible and fixed exchange rate regimes increases for larger values of $\Phi$.

Whereas, as in the benchmark case, consumption is fully crowded out by the fiscal expansion under fixed exchange rates, it rises upon impact under flexible exchange rates. This is due to the the rise in sovereign risk and subsequent fall in the effective real rate of return on bonds, which according to the household's firstorder condition, (14), induces households to reduce their holdings of government

\footnotetext{
${ }^{13}$ This can be shown as follows. Under fixed exchange rates, $e_{t}=e$ for all $t$ and the UIP condition (17) becomes $\left(1-E_{t} \delta_{t+1}\right) R_{t}=R_{t}^{*} \Xi_{t}$. Using this expression to substitute for $R_{t}$ in the public's budget constraint, (6), the household's Euler equation, (14), and the balance of payments condition, (27), the sovereign default probability, $\delta_{t}$, can be eliminated from the model for $\chi_{2}=0$.
} 
Figure 5: Flex vs. fixed: differences in impact output responses under sovereign risk between flexible and fixed exchange rate regimes
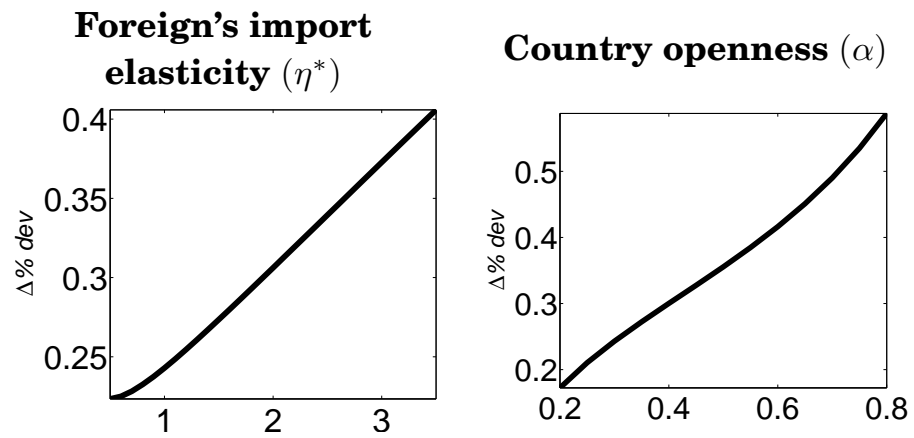

Notes: Figures show differences in impact output responses (in percentage deviation from steady state) under flexible and fixed exchange rates, measured by $\Delta \%$ dev $=\%$ dev $_{\text {flex }}-\%$ dev fixed , for different values of $\eta^{*}$ and $\alpha$, while keeping remaining parameters fixed at their benchmark values (reported in Table 1).

bonds and raise consumption. The effects of sovereign risk on consumption are therefore positive and increasing in the intertemporal elasticity of substitution (yet die out quickly as the central bank raises the policy rate to curtail inflation). In the following sub-section, we consider the case where sovereign risk has a negative effect on household consumption through its effect on the private risk premium.

\subsection{Implications of sovereign risk pass-through}

The main results from the previous sub-section carry over to the case in which the risk premium on household loans depends on sovereign risk: government spending raises output, yet the output response is higher under flexible than under fixed exchange rates; see the right column of Figure 3. As the figure shows, the real exchange rate now depreciates under both monetary regimes, yet the depreciation is stronger under the floating regime, resulting in a higher increase in exports than under the fixed exchange rate regime. The exchange rate effect, described previously, is therefore still present. However, the presence of sovereign risk pass-through has implications for both the response of the real exchange rate and private consumption, which we shall discuss next.

As before, when public debt is near its fiscal limit, a fiscal expansion raises $E_{t} \delta_{t+1}$, which leads Foreign investors to reduce their holdings of government bonds and causes the real exchange rate to depreciate. If the economy experiences sovereign risk pass-through, a rise in the sovereign default probability also raises tensions in the private credit market. Therefore, as $E_{t} \delta_{t+1}$ rises, Foreign investors demand a higher return on household loans and, according to Equation (10), the private risk premium rises. As shown in the right column of Figure 4, the risk premium rises under both monetary regimes following the fiscal expansion. By Equation (28), the rise in the risk premium further raises the nominal exchange rate, causing the real exchange rate to depreciate by more (and exports to rise by more) than in the previous case without sovereign risk pass-through. The real 
exchange rate now also depreciates under the fixed exchange rate regime, which, given that the nominal exchange rate remains constant, indicates a fall in inflation; we will come back to this point later.

The response of consumption upon the rise in government spending is now negative under both monetary regimes, owing to the presence of the sovereign risk channel explained in Section 3.2. The consumption response can be explained by the log-linearised version of the household's Euler equation for private debt, (13), iterated forward:

$$
\sigma \hat{C}_{t}=\sigma \lim _{s \rightarrow \infty} E_{t} \hat{C}_{t+s}-E_{t} \sum_{j=0}^{\infty} \hat{\pi}_{t+1+j}-E_{t} \sum_{j=0}^{\infty} \hat{\Xi}_{t+j}^{*}+\hat{e}_{t}-\lim _{s \rightarrow \infty} E_{t} \hat{e}_{t+s}
$$

For transitory shocks, the limits in (30) equal zero. The change in household consumption, $\hat{C}_{t}$, then depends on changes in inflation, $E_{t} \sum_{j=0}^{\infty} \hat{\pi}_{t+1+j}$, and the risk premium, $E_{t} \sum_{j=0}^{\infty} \hat{\Xi}_{t+j}^{*}$, which both tend to reduce consumption, and changes in the nominal exchange rate, $\hat{e}_{t}$, which raise consumption. As the risk premium rises, following the increase in sovereign risk, households respond by borrowing less and reducing consumption. As shown in Figure 3, the net effect of the government spending shock on $\hat{C}_{t}$ is negative under both flexible and fixed exchange rates. In fact, household consumption is crowded out by more than in the case where sovereign risk pass-through was assumed absent. We refer to this effect as the "sovereign risk pass-through effect". Note, however, that the reduction in consumption is less pronounced under flexible than fixed exchange rates due to the rise in $\hat{e}_{t}$; also, the adverse effects on consumption are weakened by the fall in the effective real rate of return on government debt, which, as discussed in Section 4.2, tends to raise consumption. ${ }^{14}$

Under our benchmark calibration, we find that the output response following the fiscal expansion is positive under both monetary regimes, despite the crowdingout effects on consumption induced by the increase in sovereign risk. Under flexible exchange rates, the output response is increasing $\Phi$, suggesting the exchange rate effect dominates the sovereign risk pass-through effect (see Figure 9 in the Appendix). Under fixed exchange rates, the exchange rate effect is eliminated due to intervention by the central bank. Therefore, the effects of the government spending shock on output depend on the rise in public demand versus the fall in private demand. In any case, we find that the output response is lower under fixed than under flexible exchange rates, again going against conventional wisdom. Also, as shown by Figure 10 in the Appendix, when the spillover effects from public to private borrowing costs are very high, e.g. $\chi_{2}=0.33$, and household consumption is crowded out to a large extent, the impact response of output under fixed exchange rates is even negative.

Note that, even though the instantaneous response of output can be negative under fixed exchange rates, the responses are positive in the medium and long

\footnotetext{
${ }^{14}$ The effects of sovereign risk on the exchange rate (and consumption) in the presence of sovereign risk pass-through would remain, even if we assumed a number of households to be non-Ricardian. What matters is that the risk premium on private loans goes up as soon as sovereign risk rises, which, according to the UIP condition, forces the real exchange rate to depreciate. Inclusion of nonRicardian households does not remove this role of the UIP condition; only if all households were non-Ricardian would sovereign risk pass-through cease to have an effect on the exchange rate.
} 
run, as shown in the right column of Figure 10. The assumed rigidity in intermediate goods prices underlie these dynamics and can be explained as follows. The increase in government spending, and the associated rise in sovereign risk, has a positive effect on the risk premium on household loans and hence reduces private consumption. Under flexible exchange rates, the fall in domestic demand is offset by an increase in foreign demand, owing to the exchange rate effect, and output rises; in the medium- to long run, output gradually returns to steady state as firms are able to adjust their prices upwards. Under fixed exchange rates, however, the nominal exchange rate does not respond to changes in sovereign risk and thus there are no direct offsetting effects from foreign demand. Without a depreciation of the nominal exchange rate, and without the ability of sticky price firms to adjust their prices, the reduction in consumption is translated into a fall in output. Flexible price firms, on the other hand, respond to the fall in consumption by lowering their prices, which reduces CPI inflation and leads to a depreciation of the real exchange rate. As time goes by, more firms are able to set their prices lower, stimulating aggregate demand and raising output.

Recall that, in our current set-up, the central bank controls the interest rate on government bonds and investors are unable to respond to changes in sovereign risk by adjusting the bonds price; instead, they must respond by changing their demand for bonds. ${ }^{15}$ If it were possible to partially insure against sovereign default risk (e.g. through renegotiation of the bonds price), the change in foreign demand for government debt due to sovereign risk, and the associated responses of the real exchange rate and exports, would be mitigated. However, the real exchange rate would still respond to changes in the quality of private debt, even when holders of government debt are completely insured against the risk of sovereign default. This is because of the assumed link between public and private credit conditions, against which foreign lenders cannot perfectly insure. Therefore, an increase in sovereign risk would still lead to an exchange rate depreciation and a rise in output under a floating exchange rate regime, whereas the effects on output would be predominately negative under a fixed exchange rate regime. In Appendix $\mathrm{C}$, we illustrate this result, and thereby also demonstrate the robustness of our results, by considering the case in which holders of government bonds are completely insured against changes in sovereign risk, while still allowing for the presence of a sovereign risk channel.

The figures displayed in the right column of Figure 3 correspond to the empirical findings reported in Section 2: countries experiencing high fiscal strain, and without access to an exchange rate mechanism to absorb changes in sovereign risk, will find it increasingly difficult to stabilise the economy through fiscal policy. Furthermore, our model shows that the extent to which sovereign risk affects private sector interest rates matters for the effectiveness of fiscal policy.

\footnotetext{
${ }^{15}$ In a related paper, van der Kwaak and van Wijnbergen (2013) focus on the propagation of valuation effects of government bonds through bank's balance sheets when banks are also unable to fully insure themselves against the risk of a sovereign default.
} 


\section{Application: expansionary fiscal contractions}

Can fiscal contractions be expansionary? This question, originally raised by Giavazzi and Pagano (1990), has prompted a large literature and political debate. ${ }^{16}$ In their paper, Giavazzi and Pagano make an excellent account of an increase in private consumption that occurred during substantive fiscal contractions in Denmark and Ireland during the 1980s. Such potential 'non-Keynesian' effects of fiscal policy can be explained by the so-called "credibility channel": a credible fiscal retrenchment reduces default expectations, which lowers the risk premium on government bonds and the real interest rate and boosts private spending.

Using the model presented in Section 3, we assess this 'expansionary fiscal consolidation hypothesis' by simulating the response of output upon a reduction in government spending. According to the hypothesis, the strength of the credibility channel depends (amongst other things) on the relationship between the level of government debt and the real interest rate, which is one of the main features of our model. We therefore examine the effects of a fiscal contraction for different values of $\Phi$ and $\chi_{2}$. In particular, we ask: how much fiscal strain (captured by $\Phi$ ) and sovereign risk pass-through (captured by $\chi_{2}$ ) is required in order for a fiscal consolidation to be expansionary? Also, what is the role of the monetary regime?

The top-left quadrant of Figure 6 suggests that, under flexible exchange rates, a reduction in government consumption leads to output losses for any degree of fiscal strain and feedback between public and private credit risk. In fact, the larger are $\Phi$ and $\chi_{2}$, the stronger is the output loss upon a fiscal contraction. This result follows from our discussion in Section 4.2, in which we showed that the real exchange rate is positively correlated with the amount of sovereign risk. As the fiscal contraction reduces the stock of debt, sovereign risk falls such that Foreign investors are induced to increase their holdings of Home assets. Reallocation of Foreign's asset portfolio puts downward pressure on the real exchange rate, i.e. the real exchange rate appreciates, which in turn has a negative effect on output; the larger is the default elasticity with respect to public debt, the stronger is the response of Foreign investors to an improvement of the fiscal balance and the greater is the pressure on the exchange rate and aggregate production.

Under fixed exchange rates, however, a fiscal consolidation can generate positive output responses, at least for high degrees of fiscal strain and sovereign risk pass-through. Again, the reduction in the public debt level restores confidence in financial markets and raises demand for government bonds by foreign investors. However, unlike under flexible exchange rates, the rise in foreign demand for government debt does not lead to an appreciation of the exchange rate. Hence, the response of output following the fiscal consolidation is driven by the response of household consumption. The latter rises upon a fall in public spending due to a reduction in the risk premium on household loans. Therefore, if the pass-through from sovereign risk to the private risk premium is large enough, i.e. if $\chi_{2}$ is sufficiently high, then the net effect on output following a fiscal consolidation can become positive (see top-right quadrant of Figure 6).

The fiscal consolidation hypothesis rests on the assumption of forward-looking

\footnotetext{
${ }^{16}$ Sutherland (1997), Alesina and Ardagna (1998) and Perotti (1999) are significant contributions. Recently, the debate has resurfaced with contributions from Alesina and Ardagna (2010), Leigh et al. (2011) and Jordà and Taylor (2013), among others.
} 
Figure 6: Output responses to a fiscal contraction

Flexible exchange rate
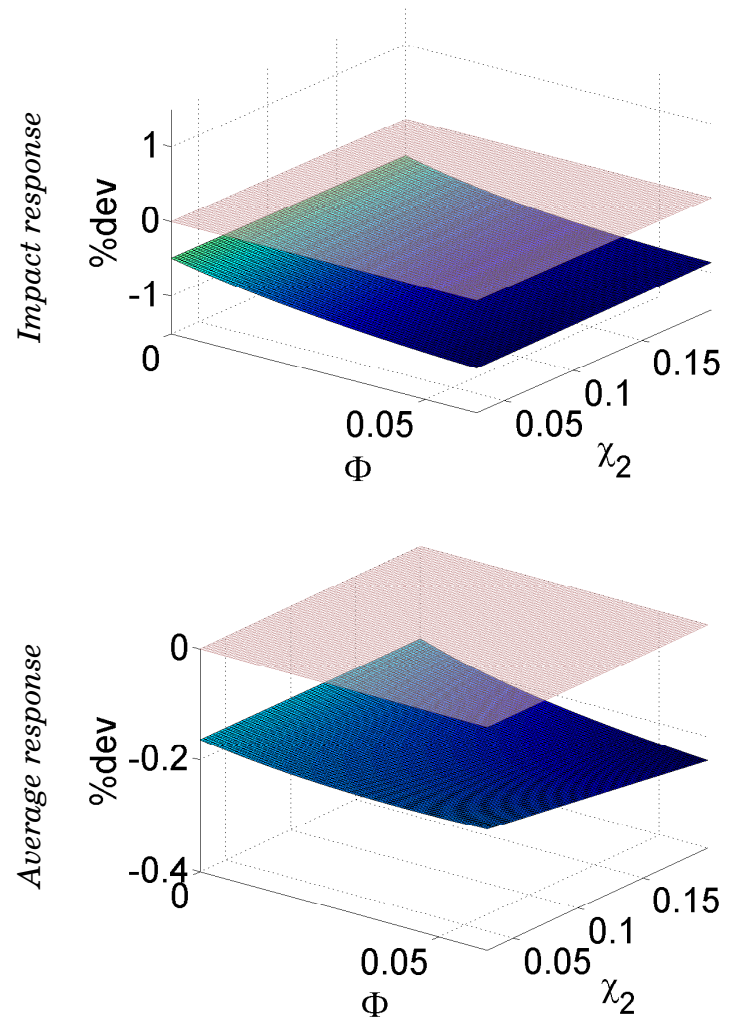

Fixed exchange rate
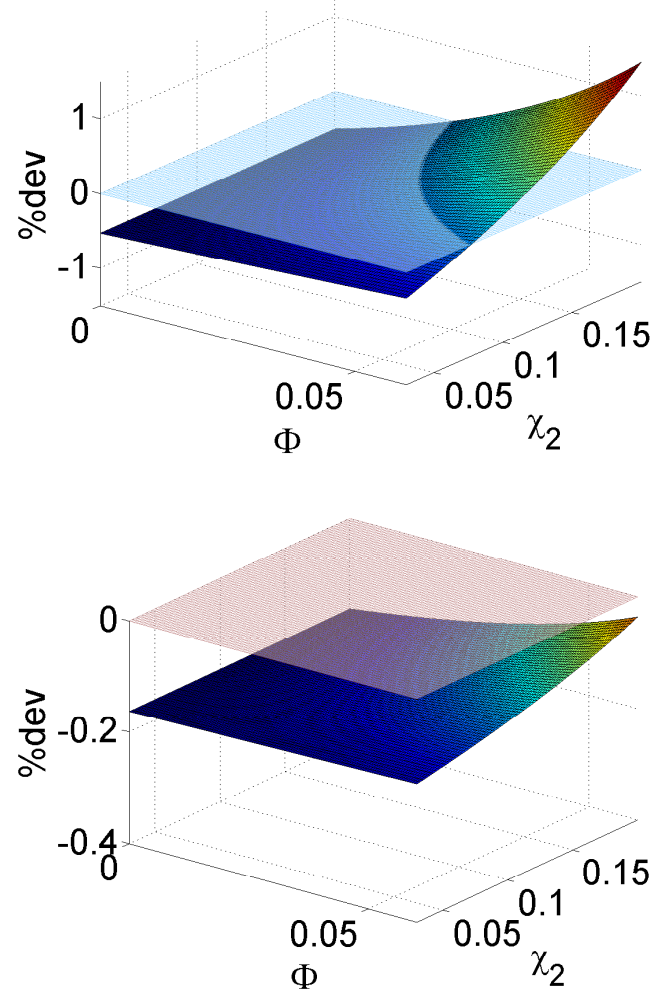

Notes: Figures show impact and average output responses (vertical axes) upon a fall in government spending (of $1 \%$ of output) for different default elasticities, $\Phi \in[0.00,0.06]$, and degrees of sovereign risk pass-through, $\chi_{2} \in[0.00,0.20]$, under flexible and fixed exchange rates.

behaviour of agents. For instance, fiscal consolidation admits a positive response of private consumption if households expect a reduction in taxes and/or an increase in government transfers in the future. As shown by Coenen et al. (2008), a fiscal retrenchment that leads to a reduction in outstanding government debt and lower total interest rate payments can raise the possibility of a drop in the level of distortionary taxes, which increases investment and output in the long run. These positive effects become more pronounced when allowing for a relationship between the level of government debt and the equilibrium real interest rate. Since the top row in Figure 6 shows the impact responses of output upon a fall in government consumption, and might conceal potential positive long-run effects of the fiscal consolidation, we also simulate the cumulative responses divided by the number of periods under consideration, i.e. 20 periods (or 5 years), which we refer to as the 'average (output) response'. Again, we perform the simulations for different degrees of fiscal strain and sovereign risk pass-through.

The results are shown in the bottom row of Figure 6. Under flexible exchange rates, the average effects on output are again dictated to a large extent by the sovereign default elasticity and its interaction with the real exchange rate. Higher 
measures of $\Phi$ result in greater output losses for a given reduction in government spending (see bottom-left quadrant of Figure 6). Under fixed exchange rates, we observe that the average output response to a government spending cut is also negative for all combinations of $\Phi$ and $\chi_{2}$. This result follows from our discussion in Section 4.3. For a high degree of sovereign risk pass-through and fiscal strain, the impact response of output can be positive under fixed exchange rates, due to the reduction in the risk premium on household loans and the associated increase in private spending. Due to price stickiness, firms respond by raising production, which allows for an increase in output. In the medium- to long run, however, prices become more flexible and firms raise their prices in order to benefit from the increase in private demand; the higher price level causes spending to fall and pushes output downwards, completely offsetting the initial positive effect on output (see bottom-right quadrant of Figure 6).

To summarise, it is possible for a fiscal consolidation to generate a positive output response, yet only in the presence of considerable fiscal strain and sovereign risk pass-through. In addition, a fiscal contraction is only favourable in terms of output gains under fixed exchange rates and only in the short run.

Our findings correspond with those reported by Perotti (2012), who re-examined four classic case studies on fiscal consolidation: two (Denmark and Ireland) under fixed exchange rates and two (Finland and Sweden) under flexible exchange rates. In line with the predictions of our model, the fiscal consolidation in Denmark resulted in a reduction of long-term real interest rates and an expansion in domestic demand, primarily driven by an increase in private consumption. The other consolidation episodes were also associated with expansions, yet were mainly driven by a substantial depreciation of the exchange rate (due to abandonment of an exchange rate peg just in advance of the fiscal consolidation in the case of Finland and Sweden) and the consequent growth in exports.

\section{Conclusion}

Recent sovereign debt crises in a number of advanced economies have highlighted the importance of public debt sustainability for fiscal stabilisation policy. In this paper, we have examined the implications of sovereign risk for fiscal policy effectiveness under different monetary regimes. Specifically, we have shown, both empirically and theoretically, that in the presence of sovereign risk, a government spending shock can generate higher output responses under flexible than under fixed exchange rates, which stands in contrast to both the traditional MundellFleming paradigm and conventional New Keynesian wisdom.

Intuitively, an increase in the probability of sovereign default, following a rise in government spending, leads to a fall in foreign demand for domestic assets. The consequent nominal exchange rate depreciation under a float supports aggregate output through an increase in exports, especially when the elasticity of substitution between foreign and domestic goods and the degree of country openness are large. Under fixed exchange rates, however, the favourable relative price change is eliminated through central bank intervention. Hence, the crowding-out effects of the fiscal expansion dominate and the output response is lower than under flexible exchange rates. 
Our model and empirical exercise formalise the discussion in De Grauwe (2012), in which it is argued that a rise in sovereign default beliefs can have 'positive externalities' provided sovereign debt is largely denominated in domestic currency and the exchange rate is allowed to act as a natural adjustment mechanism. Countries experiencing fiscal strain and whose external debt is denominated in foreign currency, however, face a higher probability of falling into unstable equilibria, characterised by explosive debt developments. Our results are therefore particularly relevant for countries that are struggling with weak pubilc finances, while contemplating to anchor their exchange rate or adopt a common currency.

Finally, we have shown that it is possible for a fiscal consolidation to generate a positive output response, yet only in the presence of considerable fiscal strain and sovereign risk pass-through. In addition, a fiscal contraction is favourable in terms of output gains only under fixed exchange rates and only in the short run; in the long run, fiscal consolidations are contractionary, irrespective of the exchange rate regime. Whether these results can be confirmed empirically is a venue we leave for future work. 


\section{References}

Acharya, V. V., Drechsler, I., and Schnabl, P. (2011). A pyrrhic victory? Bank bailouts and sovereign credit risk. NBER Working Papers 17136, National Bureau of Economic Research.

Albertazzi, U., Ropele, T., Sene, G., and Signoretti, F. (2012). The impact of the sovereign debt crisis on the activity of Italian banks. Bank of Italy Occasional paper 133, Bank of Italy.

Alesina, A. and Ardagna, S. (1998). Tales of fiscal adjustment. Economic Policy, 13(27):487-545.

Alesina, A. and Ardagna, S. (2010). Large changes in fiscal policy: taxes versus spending. In Tax Policy and the Economy, volume 24 of NBER Chapters, pages 35-68. National Bureau of Economic Research.

Andritzky, M. J. R. (2012). Government bonds and their investors: What are the facts and do they matter? IMF Working Paper 12-158, International Monetary Fund.

Angeloni, C. and Wolff, G. B. (2012). Are banks affected by their holdings of government debt? Bruegel Working Paper 7, Bruegel.

Ardagna, S., Caselli, F., and Lane, T. (2007). Fiscal discipline and the cost of public debt service: some estimates for OECD countries. The BE Journal of Macroeconomics, 7(1).

Auerbach, A. and Gorodnichenko, Y. (2012). Fiscal multipliers in recession and expansion. In Fiscal Policy after the Financial Crisis, NBER Chapters. National Bureau of Economic Research.

Ballabriga, F. and Martinez-Mongay, C. (2010). Sustainability of EU public finances. Economic Papers 225, European Commission.

Bi, H. (2012). Sovereign default risk premia, fiscal limits, and fiscal policy. European Economic Review, 56:389-410.

Bohn, H. (1998). The behavior of U.S. public debt and deficits. The Quarterly Journal of Economics, 113(3):949-963.

Born, B., Juessen, F., and Müller, G. J. (2013). Exchange rate regimes and fiscal multipliers. Journal of Economic Dynamics and Control, 37(2):446-465.

Bouakez, H. and Eyquem, A. (2012). Government spending, monetary policy, and the real exchange rate. Cahiers de recherche 1212, CIRPEE.

Bruyckere, V., Gerhardt, M., Schepens, G., and Vander Vennet, R. (2012). Bank/sovereign risk spillovers in the European debt crisis. National Bank of Belgium Working Paper 232, National Bank of Belgium.

Buiter, W. and Rahbari, E. (2013). Why do governments default, and why don't they default more often? CEPR Working Papers 9492, Centre for Economic Policy Research. 
Calvo, G. A. (1983). Staggered prices in a utility-maximizing framework. Journal of Monetary Economics, 12(3):383-398.

Coenen, G. et al. (2012). Effects of fiscal stimulus in structural models. American Economic Journal: Macroeconomics, 4(1):22-68.

Coenen, G., Mohr, M., and Straub, R. (2008). Fiscal consolidation in the Euro area: long-run benefits and short-run costs. Economic Modelling, 25(5):912-932.

Corsetti, G., Kuester, K., Meier, A., and Müller, G. J. (2013). Sovereign risk, fiscal policy, and macroeconomic stability. The Economic Journal, 123(566):F99-F132.

Corsetti, G., Kuester, K., and Müller, G. J. (2011). Floats, pegs and the transmission of fiscal policy. Journal Economía Chilena (The Chilean Economy), 14(2):5-38.

Corsetti, G., Meier, A., and Müller, G. J. (2012). What determines government spending multipliers? Economic Policy, 27(72):521-565.

Cottarelli, C. and Jaramillo, L. (2012). Walking hand in hand: Fiscal policy and growth in advanced economies. IMF Working Papers 12/137.

Davig, T., Leeper, E. M., and Walker, T. B. (2010). "Unfunded liabilities" and uncertain fiscal financing. Journal of Monetary Economics, 57(5):600-619.

De Grauwe, P. (2012). The governance of a fragile Eurozone. Australian Economic Review, 45(3):255-268.

Demirgüç-Kunt, A. and Huizinga, H. (2013). Are banks too big to fail or too big to save? International evidence from equity prices and CDS spreads. Journal of Banking and Finance, 37(3):875-894.

Durbin, E. and Ng, D. (2005). The sovereign ceiling and emerging market corporate bond spreads. Journal of International Money and Finance, 24(4):631-649.

Eaton, J. and Gersovitz, M. (1981). Debt with potential repudiation: theoretical and empirical analysis. The Review of Economic Studies, 48(2):289-309.

Galí, J., Lopéz-Salido, J. D., and Vallés, J. (2007). Understanding the effects of government spending on consumption. Journal of the European Economic Association, 5(1):227-270.

Galí, J. and Monacelli, T. (2005). Monetary policy and exchange rate volatility in a small open economy. The Review of Economic Studies, 72(3):707-734.

Galí, J. and Monacelli, T. (2008). Optimal monetary and fiscal policy in a currency union. Journal of International Economics, 76(1):116-132.

Giavazzi, F. and Pagano, M. (1990). Can severe fiscal contractions be expansionary? Tales of two small European countries. In NBER Macroeconomics Annual 1990, Volume 5, pages 75-122. MIT Press.

Harjes, T. (2011). Financial integration and corporate funding costs in Europe after the financial and sovereign debt crisis. Euro Area Policies: Selected Issues. 
Hebous, S. (2011). The effects of discretionary fiscal policy on macroeconomic aggregates: a reappraisal. Journal of Economic Surveys, 25(4):674-707.

Ilzetzki, E., Mendoza, E. G., and Végh, C. A. (2012). How big (small?) are fiscal multipliers? Journal of Monetary Economics, 60(2):239-254.

Ilzetzki, E., Reinhart, C. M., and Rogoff, K. S. (2010). Exchange rate arrangements entering the 21st century: Which anchor will hold? mimeo.

IMF (2010). The uses and abuses of sovereign credit ratings. In Global Financial Stability Report, volume October 2010, chapter 3, pages 85-122. IMF.

Jordà, O. and Taylor, A. (2013). The time for austerity: estimating the average treatment effect of fiscal policy. Paper presented at the NBER Summer Institute.

Lane, P. R. and Milesi-Ferretti, G. M. (2002). Long-Term Capital Movements, volume 16 of NBER Chapters, pages 73-136. MIT Press.

Laubach, T. (2009). New evidence on the interest rate effects of budget deficits and debt. Journal of the European Economic Association, 7(4):858-885.

Leigh, D., Pescatori, A., and Guajardo, J. (2011). Expansionary austerity: new international evidence. IMF Working Papers 11/158, International Monetary Fund.

Perotti, R. (1999). Fiscal policy when things are going badly. Quarterly Journal of Economics, 114(4):1399-1436.

Perotti, R. (2012). The "austerity myth": gain without pain? In Fiscal Policy after the Financial Crisis. University of Chicago Press.

Schabert, A. and van Wijnbergen, S. (2011). Sovereign default and the stability of inflation targeting regimes. Tinbergen Institute Discussion Papers 11-064/2/ DSF20, Tinbergen Institute.

Schmitt-Grohé, S. and Uribe, M. (2003). Closing small open economy models. Journal of International Economics, 61(1):163-185.

Sutherland, A. (1997). Fiscal crises and aggregate demand: can high public debt reverse the effects of fiscal policy? Journal of Public Economics, 65(2):147-162.

Taylor, J. B. (1993). Discretion versus policy rules in practice. Carnegie-Rochester conference series on public policy, 39:195-214.

Uribe, M. (2006). A fiscal theory of sovereign risk. Journal of Monetary Economics, 53(8):1857-1875.

van der Kwaak, C. and van Wijnbergen, S. (2013). Long term government debt, financial fragility and sovereign default risk. Tinbergen Institute Discussion Papers 13-052/VI/DSF 55, Tinbergen Institute.

Zoli, M. E. (2013). Italian sovereign spreads: Their determinants and pass-through to bank funding costs and lending conditions. IMF Working Paper 13-84, International Monetary Fund. 


\section{A Equilibrium conditions}

In this section, we briefly present the equilibrium conditions that were omitted from the main text for the sake of exposition.

\section{A.1 Optimal demand schedules and price indices}

\section{Government consumption}

The CES aggregator governing government consumption, $G_{t}$, consists of consumption on domestically produced goods, $G_{H t}$, and imported goods, $G_{F t}$, i.e.:

$$
G_{t} \equiv\left[(1-\alpha)^{\frac{1}{\eta}}\left(G_{H t}\right)^{\frac{\eta-1}{\eta}}+\alpha^{\frac{1}{\eta}}\left(G_{F t}\right)^{\frac{\eta-1}{\eta}}\right]^{\frac{\eta}{\eta-1}},
$$

where $\alpha \in[0,1)$ measures the weight of imported goods in total public consumption, such that $1-\alpha$ measures the degree of home bias, and $\eta>0$ is the constant elasticity of substitution between domestic and foreign goods. The government allocates its consumption between $G_{H t}$ and $G_{F t}$ by maximising (31) subject to the constraint $P_{t} G_{t} \geq P_{H t} G_{H t}+P_{F t} G_{F t}$, where $P_{H t}$ and $P_{F t}$ are the aggregate domestic price levels of Home and Foreign, respectively (denominated in Home currency). This results in the following optimal demand schedules,

$$
G_{H t}=(1-\alpha)\left(\frac{P_{H t}}{P_{t}}\right)^{-\eta} G_{t}, \quad G_{F t}=\alpha\left(\frac{P_{F t}}{P_{t}}\right)^{-\eta} G_{t},
$$

and CPI equation,

$$
P_{t}=\left[(1-\alpha) P_{H t}^{1-\eta}+\alpha P_{F t}^{1-\eta}\right]^{\frac{1}{1-\eta}} .
$$

\section{Household consumption}

Total household consumption, $C_{t}$, is a composite index determined by consumption on domestically produced goods, $C_{H t}$, and imported goods, $C_{F t}$, defined by:

$$
C_{t} \equiv\left[(1-\alpha)^{\frac{1}{\eta}}\left(C_{H t}\right)^{\frac{\eta-1}{\eta}}+\alpha^{\frac{1}{\eta}}\left(C_{F t}\right)^{\frac{\eta-1}{\eta}}\right]^{\frac{\eta}{\eta-1}},
$$

where

$$
C_{H t}=(1-\alpha)\left(\frac{P_{H t}}{P_{t}}\right)^{-\eta} C_{t}, \quad C_{F t}=\alpha\left(\frac{P_{F t}}{P_{t}}\right)^{-\eta} C_{t} .
$$

Similarly, Foreign demand for Foreign goods, $C_{F t}^{*}$, and Home goods, $C_{H t}^{*}$, is given by:

$$
C_{H t}^{*}=\alpha^{*}\left(\frac{P_{H t}^{*}}{P_{t}^{*}}\right)^{-\eta^{*}} C_{t}^{*}, \quad C_{F t}^{*}=\left(1-\alpha^{*}\right)\left(\frac{P_{F t}^{*}}{P_{t}^{*}}\right)^{-\eta^{*}} C_{t}^{*},
$$

where $\alpha^{*} \leq \alpha$ is a measure of Foreign's degree of openness with respect to Home, reflecting the relatively small size of Home, $\eta^{*}>0$ measures Foreign's import demand elasticity, $P_{H t}^{*}$ is the aggregate domestic price level of Home, $P_{F t}^{*}$ is the aggregate domestic price level of Foreign, $P_{t}^{*}$ is Foreign's aggregate CPI index and $C_{t}^{*}$ is Foreign aggregate consumption. 


\section{Firm demand and price setting}

The final goods firm combines intermediate goods to produce the final good, $Y_{t}$, using a standard CES production function,

$$
Y_{t}=\left[\int_{0}^{1} Y_{t}(i)^{\frac{\epsilon-1}{\epsilon}} d i\right]^{\frac{\epsilon}{\epsilon-1}}
$$

where $i \in[0,1]$ is the intermediate goods firm index and $\epsilon>1$ is the constant elasticity of substitution between intermediate goods. Minimisation of the costs of assembling $Y_{t}$, subject to (37), results in the optimal demand schedule for goods produced by intermediate goods firm $i$, (18), and the Home aggregate domestic price level, $P_{H t}$, as given by (19).

The intermediate goods firm, on the other hand, uses the linear production function (20) and aims to maximise current and expected future profits, subject to (18) and (20), while taking the nominal wage rate and the probability of non-price adjustment in the future as given:

$$
\max _{\bar{P}_{H t}} E_{0} \sum_{k=0}^{\infty} \theta^{k} Q_{t, t+k}\left[\bar{P}_{H t} Y_{t, t+k}(i)-W_{t+k} N_{t, t+k}(i)\right]
$$

where $\bar{P}_{H t}$ is the optimal re-set price ${ }^{17}, Q_{t, t+k} \equiv \beta^{k}\left(1-\delta_{t+k}\right)\left(\frac{C_{t+k}}{C_{t}}\right)^{-\sigma} / \pi_{t+k}$ is the stochastic discount factor for nominal pay-offs in period $t+k$ (see [14]) and $Y_{t, t+k}(i)$ is the amount of output produced by firm $i$ who last re-set its price in period $t$. The optimal re-set price that follows is a mark-up $\mathcal{M} \equiv \epsilon /(\epsilon-1)$ over current and expected real marginal costs, given by (22).

\section{A.2 Exports}

The expression for Home exports, (25), is derived as follows. First, rewrite the CPI equation, (33), using the law of one price, $P_{F t}=e_{t} P_{F t}^{*}=e_{t} P_{t}^{*}$ and the definition of the real exchange rate, $q_{t}=e_{t} P_{t}^{*} / P_{t}$ :

$$
P_{t}=\left[(1-\alpha) P_{H t}^{1-\eta}+\alpha\left(q_{t} P_{t}\right)^{1-\eta}\right]^{\frac{1}{1-\eta}} .
$$

Then, divide by $P_{t}$ and solve for $P_{H t} / P_{t}$ :

$$
\begin{aligned}
1 & =\left[(1-\alpha)\left(\frac{P_{H t}}{P_{t}}\right)^{1-\eta}+\alpha q_{t}^{1-\eta}\right]^{\frac{1}{1-\eta}}, \\
\frac{P_{H t}}{P_{t}} & =\left(\frac{1-\alpha q_{t}^{1-\eta}}{1-\alpha}\right)^{\frac{1}{1-\eta}} .
\end{aligned}
$$

\footnotetext{
${ }^{17}$ Note that the optimal re-set price is not firm-specific due to symmetry among firms.
} 
Finally, to obtain the equation for Home exports, $X_{t} \equiv C_{H t}^{*}$, rewrite the Foreign demand schedule for Home goods, (36), by substituting $P_{H t} / P_{t}$ :

$$
\begin{aligned}
X_{t} & =\alpha^{*}\left(\frac{P_{H t}^{*}}{P_{t}^{*}}\right)^{-\eta^{*}} C_{t}^{*}=\alpha^{*} q_{t}^{\eta^{*}}\left(\frac{P_{H t}}{P_{t}}\right)^{-\eta^{*}} C_{t}^{*} \\
& =\alpha^{*}\left(\frac{q_{t}^{\eta-1}-\alpha}{1-\alpha}\right)^{\frac{\eta^{*}}{\eta-1}} C_{t}^{*} .
\end{aligned}
$$

\section{B Log-linearisation}

Here, we derive the log-linearised equilibrium conditions. Define variables with a hat as the percentage deviation of that variable from its steady-state level and variables without a $t$ subscript as the steady-state level of the corresponding variable, e.g. $\hat{x}_{t} \equiv\left(x_{t}-x\right) / x$, for any variable $x_{t}$. Throughout, we assume that Foreign consumption and inflation and the Foreign nominal interest rate remain constant, i.e. $C_{t}^{*}=C^{*}, \pi_{t}^{*}=\pi^{*}$ and $R_{t}^{*}=R^{*}$ for all $t$.

We start by deriving the pricing conditions. Log-linearisation of the CPI equation, (33), the real exchange rate and the law of one price gives:

$$
\begin{aligned}
\hat{P}_{t} & =(1-\alpha) \hat{P}_{H t}+\alpha \hat{P}_{F t}, \\
\hat{q}_{t} & =\hat{e}_{t}+\hat{P}_{t}^{*}-\hat{P}_{t}, \\
\hat{P}_{F t} & =\hat{e}_{t}+\hat{P}_{F t}^{*},
\end{aligned}
$$

where we used that $q=1$. Given the small size of the domestic economy, $P_{F t}^{*}=P_{t}^{*}$ and we can combine these three equations into:

$$
\hat{P}_{t}=\hat{P}_{H t}+\tilde{\alpha} \hat{q}_{t},
$$

with $\tilde{\alpha} \equiv \alpha /(1-\alpha)$. Taking first differences then yields an expression which links domestic inflation to changes in the real exchange rate:

$$
\hat{\pi}_{t}=\hat{\pi}_{H t}+\tilde{\alpha}\left(\hat{q}_{t}-\hat{q}_{t-1}\right) .
$$

An expression for the nominal exchange rate is obtained by taking first differences in the log-linearised expression of the real exchange rate equation:

$$
\hat{e}_{t}=\hat{e}_{t-1}+\hat{q}_{t}-\hat{q}_{t-1}+\hat{\pi}_{t} .
$$

Next, we derive the New Keynesian Philips curve. The aggregate price level, $P_{H t}$, consists of prices from firms that are able to set a new price, i.e. $\bar{P}_{H t}$, and those who cannot, i.e. $P_{H t}(i)=P_{H t-1}(i)$. We can therefore rewrite Equation (19) as

$$
\begin{aligned}
P_{H t} & =\left[\int_{0}^{1-\theta}\left(\bar{P}_{H t}\right)^{1-\epsilon} d i+\int_{1-\theta}^{1}\left(P_{H t-1}\right)^{1-\epsilon} d i\right]^{\frac{1}{1-\epsilon}}, \\
\left(P_{H t}\right)^{1-\epsilon} & =(1-\theta)\left(\bar{P}_{H t}\right)^{1-\epsilon}+\theta\left(P_{H t-1}\right)^{1-\epsilon} .
\end{aligned}
$$

Divide by $\left(P_{H t-1}\right)^{1-\epsilon}$ :

$$
\left(\frac{P_{H t}}{P_{H t-1}}\right)^{1-\epsilon}=(1-\theta)\left(\frac{\bar{P}_{H t}}{P_{H t-1}}\right)^{1-\epsilon}+\theta .
$$


Then, log-linearisation yields:

$$
\hat{\pi}_{H t}=(1-\theta)\left(\hat{\bar{P}}_{H t}-\hat{P}_{H t-1}\right)
$$

where $\hat{\pi}_{H t} \equiv \hat{P}_{H t}-\hat{P}_{H t-1}$. The intermediary firm's optimal re-set price, given by (22), can be written as:

$$
\frac{\bar{P}_{H t}}{P_{t-1}}=\frac{1}{P_{t-1}} \mathcal{M} \frac{E_{t} \sum_{k=0}^{\infty}(\theta \beta)^{k}\left(1-\delta_{t+k}\right) P_{t+k}^{-1} C_{t+k}^{-\sigma} P_{H t+k}^{1+\epsilon} Y_{t+k} m c_{t+k}}{E_{t} \sum_{k=0}^{\infty}(\theta \beta)^{k}\left(1-\delta_{t+k}\right) P_{t+k}^{-1} C_{t+k}^{-\sigma} P_{H t+k}^{\epsilon} Y_{t+k}} .
$$

After log-linearisation, while considering that in the flexible price equilibrium $m c=1 / \mathcal{M}$, one obtains:

$$
\hat{\bar{P}}_{H t}=(1-\theta \beta) E_{t} \sum_{k=0}^{\infty}(\theta \beta)^{k}\left(\hat{P}_{H t+k}+\hat{m} c_{t+k}\right) .
$$

Subtracting $\hat{P}_{H t-1}$ from both sides and taking out the terms for $k=0$, we have

$$
\begin{aligned}
\hat{\bar{P}}_{H t}-\hat{P}_{H t-1} & =(1-\theta \beta) E_{t} \sum_{k=0}^{\infty}(\theta \beta)^{k}\left(\hat{P}_{H t+k}-\hat{P}_{H t-1}+\hat{m} c_{t+k}\right) \\
& =(1-\theta \beta) E_{t} \sum_{k=0}^{\infty}(\theta \beta)^{k} \hat{m} c_{t+k}+E_{t} \sum_{k=0}^{\infty}(\theta \beta)^{k} \hat{\pi}_{H t+k} \\
& =(1-\theta \beta) \hat{m} c_{t}+\hat{\pi}_{H t}+\theta \beta E_{t}\left(\hat{\bar{P}}_{H t+1}-\hat{P}_{H t}\right) .
\end{aligned}
$$

Now, using (41), we derive the New Keynesian Phillips curve:

$$
\begin{aligned}
\left(\frac{\theta}{1-\theta}\right) \hat{\pi}_{H t} & =(1-\theta \beta) \hat{m} c_{t}+\beta\left(\frac{\theta}{1-\theta}\right) E_{t} \hat{\pi}_{H t+1}, \\
\hat{\pi}_{H t} & =\frac{(1-\theta)(1-\theta \beta)}{\theta} \hat{m} c_{t}+\beta E_{t} \hat{\pi}_{H t+1} .
\end{aligned}
$$

Finally, using the log-linearised version of the optimal labour demand condition, (21), and Equation (38), we can rewrite further to obtain:

$$
\begin{aligned}
\hat{\pi}_{H t} & =\lambda\left(\hat{w}_{t}+\hat{P}_{t}-\hat{P}_{H t}\right)+\beta E_{t} \hat{\pi}_{H t+1} \\
& =\lambda\left(\hat{w}_{t}+\tilde{\alpha} \hat{q}_{t}\right)+\beta E_{t} \hat{\pi}_{H t+1},
\end{aligned}
$$

where $\lambda \equiv(1-\theta)(1-\theta \beta) / \theta$.

The log-linearised versions of the equilibrium conditions, (14), (6), (27), (10) and (17), follow once we have log-linearised $1-\delta_{t}$, with $\delta_{t}=H\left(\frac{R_{t-1}}{\pi_{t}} b_{t-1}\right)$, which is:

$$
\begin{aligned}
1-\delta_{t} & \approx(1-\delta)-\delta^{\prime}\left(\frac{R_{t-1}}{\pi_{t}} b_{t-1}-\frac{R}{\pi} b\right), \\
\frac{\left(1-\delta_{t}\right)-(1-\delta)}{1-\delta} & \approx-\delta^{\prime}\left(\frac{\frac{R}{\pi} b}{1-\delta}\right)\left(\frac{\frac{R_{t-1}}{\pi_{t}} b_{t-1}-\frac{R}{\pi} b}{\frac{R}{\pi} b}\right) \\
& =-\Phi\left(\hat{R}_{t-1}-\hat{\pi}_{t}+\hat{b}_{t-1}\right),
\end{aligned}
$$


where $\Phi \equiv \delta^{\prime}(R / \pi) b /(1-\delta)$ is the elasticity of the probability of default with respect to changes in $(R / \pi) b$. The conditions are:

$$
\begin{aligned}
\sigma \hat{C}_{t}= & \sigma E_{t} \hat{C}_{t+1}-(1-\Phi)\left(\hat{R}_{t}-E_{t} \hat{\pi}_{t+1}\right)+\Phi \hat{b}_{t} \\
\hat{b}_{t}= & \left(\frac{1-\Phi}{\beta}\right)\left(\hat{R}_{t-1}-\hat{\pi}_{t}+\hat{b}_{t-1}\right)+\frac{G}{b} \hat{G}_{t}-\frac{T}{b} \hat{T}_{t} \\
\frac{f}{Y} \hat{f}_{t}^{*}= & \frac{1}{\beta} \frac{f^{*}}{Y}\left(\hat{f}_{t-1}^{*}+\hat{\Xi}_{t-1}^{*}\right)+\left[\left(\frac{1}{\beta}-1\right) \frac{f^{*}}{Y}+\tilde{\alpha}\right] \hat{q}_{t}-\frac{b_{F}}{Y} \hat{b}_{F t} \\
& +\frac{1}{\beta} \frac{b_{F}}{Y}\left[(1-\Phi)\left(\hat{R}_{t-1}-\hat{\pi}_{t}\right)-\left(\Phi \hat{b}_{t-1}-\hat{b}_{F t-1}\right)\right]-\left(\hat{Y}_{t}-\frac{C}{Y} \hat{C}_{t}-\frac{G}{Y} \hat{G}_{t}\right)_{45} \\
\hat{\Xi}_{t}^{*}= & \chi_{1} \frac{f^{*}}{Y}\left(\hat{f}_{t}^{*}+\hat{q}_{t}\right)+\chi_{2}(1-\delta) \frac{b_{F}}{Y}\left[\Phi\left(\hat{R}_{t-1}-\hat{\pi}_{t}+\hat{b}_{t-1}\right)+\frac{\delta}{1-\delta} \hat{b}_{F t}\right] \\
\hat{q}_{t}= & E_{t} \hat{q}_{t+1}-\left[(1-\Phi)\left(\hat{R}_{t}-E_{t} \hat{\pi}_{t+1}\right)-\Phi \hat{b}_{t}\right]+\hat{\Xi}_{t}^{*} .
\end{aligned}
$$

The log-linearised versions of the remaining equilibrium conditions, (12), (5), (24) and (4), are straightforward:

$$
\begin{aligned}
\varphi \hat{Y}_{t} & =\hat{w}_{t}-\sigma \hat{C}_{t} \\
\hat{T}_{t} & =\phi_{b}\left(\hat{b}_{t-1}-\hat{\pi}_{t}\right) \\
\hat{Y}_{t} & =\left[\eta \alpha\left(\frac{C+G}{Y}\right)+\eta^{*}\left(\frac{\alpha^{*}}{1-\alpha}\right) \frac{C^{*}}{Y}\right] \hat{q}_{t}+(1-\alpha)\left(\frac{C}{Y} \hat{C}_{t}+\frac{G}{Y} \hat{G}_{t}\right), \\
\hat{b}_{F t} & =\frac{b_{F}}{b} \hat{b}_{t} \\
\hat{G}_{t} & =\rho_{g} \hat{G}_{t-1}+\varepsilon_{t}^{g} .
\end{aligned}
$$

Finally, log-linearisation of the monetary policy rule under flexible exchange rates, given by (7), yields:

$$
\hat{R}_{t}=\rho_{r} \hat{R}_{t-1}+\left(1-\rho_{r}\right) \phi_{\pi} E_{t} \hat{\pi}_{t+1} .
$$

Under fixed exchange rates, the central bank adjusts the nominal interest rate so as to satisfy the UIP condition, (47), while keeping the nominal exchange rate constant, i.e.:

$$
\hat{e}_{t}=0
$$

\section{Insurance against sovereign default}

Thus far, we have assumed that the central bank controls the interest rate on government bonds, $R_{t}$. This implies that bond holders cannot respond to changes in the risk of sovereign default by adjusting the bonds price; instead, they must respond by changing their demand for bonds. Thus, when a fiscal expansion raises sovereign risk, bond holders sell domestic government bonds in exchange for (relatively more profitable) foreign assets, which gives rise to the exchange rate effect that underlies our main results. If, on the other hand, bond holders were able to partially insure against the risk of sovereign default, then the exchange rate effect would be mitigated. 
Figure 7: Output responses to government spending shock under sovereign risk pass-through and complete sovereign risk insurance for different values of $\chi_{2}$
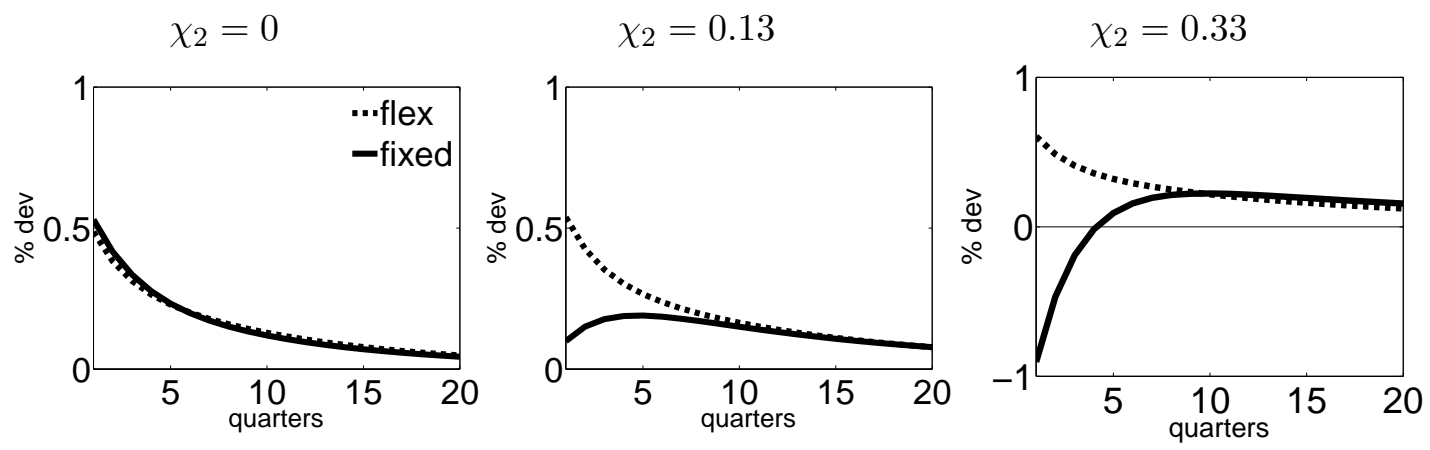

Notes: Figures are generated based on the calibration reported in Table 1.

However, as explained in Section 4.3, our results would still hold, even if government bond holders were completely insured against sovereign risk. This is because of the presence of the sovereign risk channel, which establishes a link between public and private credit risk. Since foreign lenders cannot perfectly control for changes in the riskiness of private borrowers induced by sovereign risk, an increase in the sovereign default probability would still put upward pressure on the exchange rate, at least under floating exchange rates. An increase in government spending would therefore generate qualitatively the same results as shown in Section 4.3.

In this section, we illustrate this result, and thereby also demonstrate the robustness of our previous results, by considering the case in which holders of government bonds are completely insured against changes in sovereign risk, while still allowing for the presence of a sovereign risk channel. In particular, we assume that the central bank sets the risk-free rate, $R_{t}^{f}$, rather than the bonds rate, whereas the bonds rate is determined in equilibrium by the following condition:

$$
R_{t}=\frac{1}{1-E_{t} \delta_{t+1}} R_{t}^{f}
$$

According to (55), a change in the sovereign default probability must be offset by a change in the bonds rate; thus, bond holders are completely insured against sovereign risk. We also change the monetary policy rule, given by (7), as follows:

$$
\ln \left(\frac{R_{t}^{f}}{R^{f}}\right)=\rho_{r} \ln \left(\frac{R_{t-1}^{f}}{R^{f}}\right)+\left(1-\rho_{r}\right) \phi_{\pi} \frac{E_{t} \pi_{t+1}}{\pi},
$$

and add the log-linearised version of (55) to the model.

The output responses following a government spending shock generated by the new model are shown by Figure 7. The figures are all generated under the assumption of $\delta=0.0025$ and $\Phi=0.03$; therefore, sovereign risk is present in all cases. If there is no pass-through from public to private credit risk, i.e. $\chi_{2}=0$, the output responses are higher under fixed exchange rates than under flexible exchange rates, despite the presence of sovereign risk. This result arises, because investors 
can perfectly insure themselves against changes in sovereign risk: without a response of foreign bond holders to a change in sovereign risk, the exchange rate effect is no longer present and the effects of an increase in government spending are in line with traditional Keynesian theory. However, when we allow for sovereign risk pass-through and set $\chi_{2}=0.13$, we re-obtain the result from Section 4.3 and find that the output response is higher under flexible than fixed exchange rates. In addition, when setting $\chi_{2}$ higher, e.g. $\chi_{2}=0.33$, the output response rises under the floating regime, yet becomes negative under fixed exchange rates, which is also in line with our previous results.

\section{Robustness checks}

Figure 8: Output responses to government spending shock under sovereign risk for different values of $\Phi$
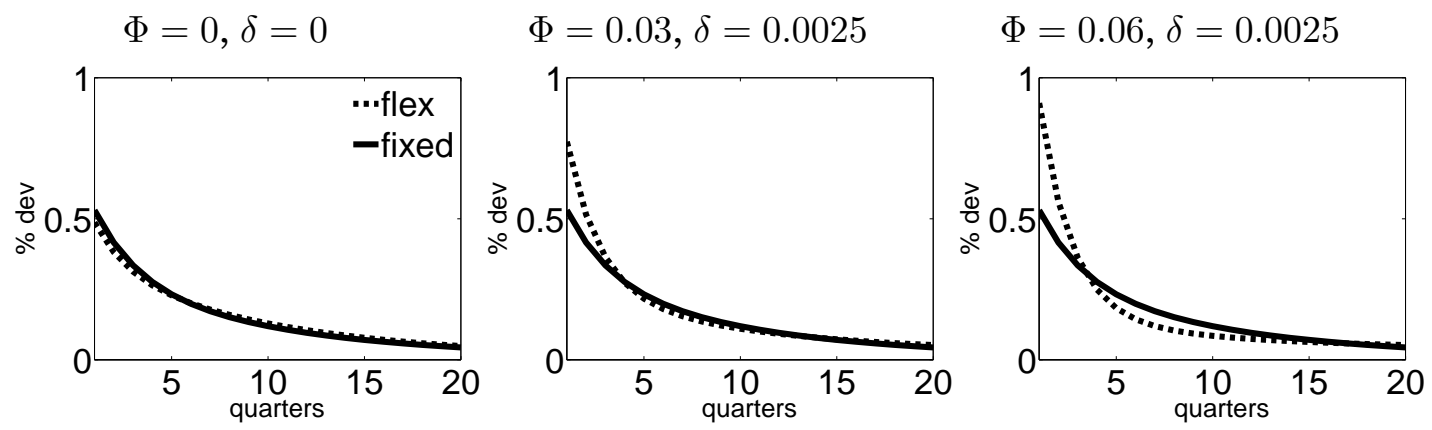

Notes: Figures are generated based on the calibration reported in Table 1, yet assuming $\chi_{2}=0$.

Figure 9: Output responses to government spending shock under sovereign risk pass-through for different values of $\Phi$
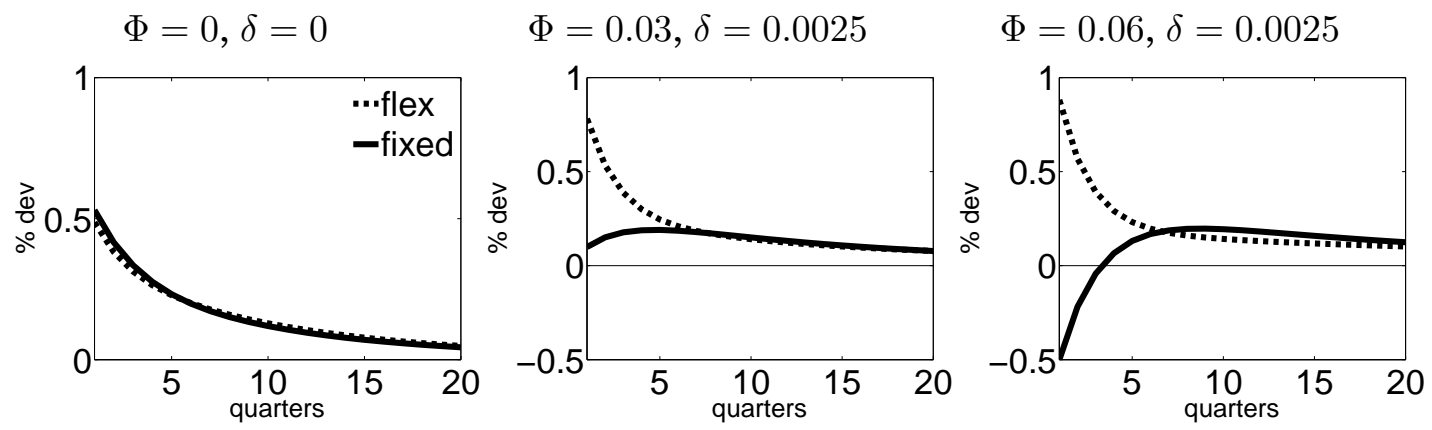

Notes: Figures are generated based on the calibration reported in Table 1. 
Figure 10: Output responses to government spending shock under sovereign risk pass-through for different values of $\chi_{2}$
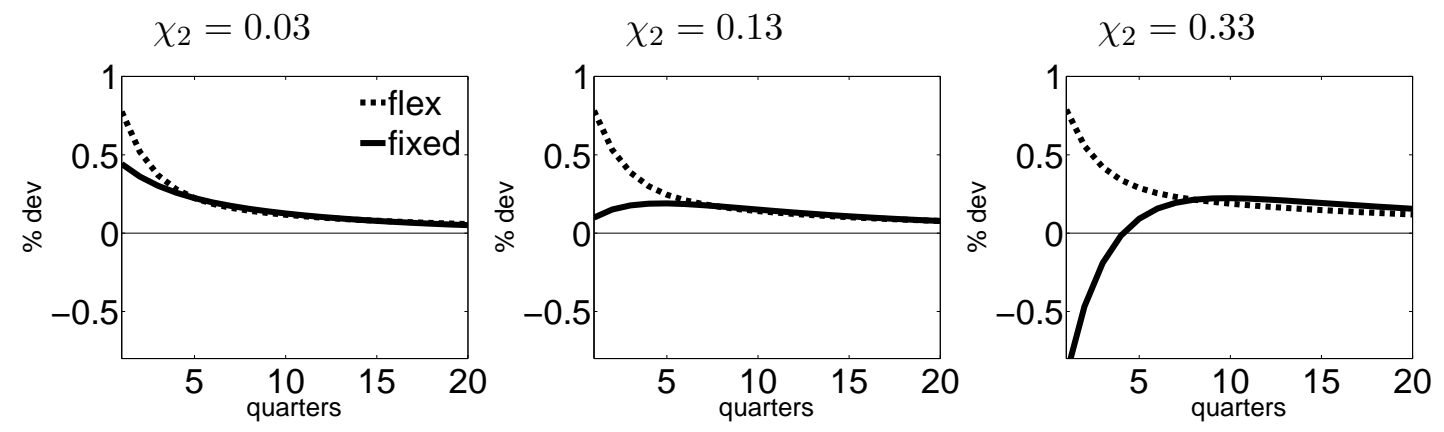

Notes: See notes under Figure 9. 